IZA DP No. 9642

Immigration and Prices: Quasi-Experimental Evidence from Syrian Refugees in Turkey

Binnur Balkan

Semih Tumen

January 2016 


\title{
Immigration and Prices: Quasi-Experimental Evidence from Syrian Refugees in Turkey
}

\author{
Binnur Balkan \\ Central Bank of the Republic of Turkey \\ Semih Tumen \\ Central Bank of the Republic of Turkey \\ and IZA \\ Discussion Paper No. 9642 \\ January 2016
}

IZA

P.O. Box 7240

53072 Bonn

Germany

Phone: +49-228-3894-0

Fax: +49-228-3894-180

E-mail: iza@iza.org

Any opinions expressed here are those of the author(s) and not those of IZA. Research published in this series may include views on policy, but the institute itself takes no institutional policy positions. The IZA research network is committed to the IZA Guiding Principles of Research Integrity.

The Institute for the Study of Labor (IZA) in Bonn is a local and virtual international research center and a place of communication between science, politics and business. IZA is an independent nonprofit organization supported by Deutsche Post Foundation. The center is associated with the University of Bonn and offers a stimulating research environment through its international network, workshops and conferences, data service, project support, research visits and doctoral program. IZA engages in (i) original and internationally competitive research in all fields of labor economics, (ii) development of policy concepts, and (iii) dissemination of research results and concepts to the interested public.

IZA Discussion Papers often represent preliminary work and are circulated to encourage discussion. Citation of such a paper should account for its provisional character. A revised version may be available directly from the author. 


\section{ABSTRACT \\ Immigration and Prices: Quasi-Experimental Evidence from Syrian Refugees in Turkey*}

We exploit the regional variation in the unexpected (or forced) inflow of Syrian refugees as a natural experiment to estimate the impact of immigration on consumer prices in Turkey. Using a difference-in-differences strategy and a comprehensive data set on the regional prices of CPI items, we find that general level of consumer prices has declined by approximately 2.5 percent due to immigration. Prices of goods and services have declined in similar magnitudes. We highlight that the channel through which the price declines take place is the informal labor market. Syrian refugees supply inexpensive informal labor and, thus, substitute the informal native workers especially in informal labor intensive sectors. We document that prices in these sectors have fallen by around 4 percent, while the prices in the formal labor intensive sectors have almost remained unchanged. Increase in the supply of informal immigrant workers generates labor cost advantages and keeps prices lower in the informal labor intensive sectors.

JEL Classification: C21, E31, J46, J61

Keywords: immigration, consumer prices, Syrian refugees, natural experiment, informal employment

Corresponding author:

Semih Tumen

Research and Monetary Policy Department

Central Bank of the Republic of Turkey

Istiklal Cad. No:10

06100 Ulus, Ankara

Turkey

E-mail: semih.tumen@tcmb.gov.tr

\footnotetext{
* We thank the seminar participants at the Central Bank of the Republic of Turkey, the participants of the 2015 IZA/World Bank Conference on Employment and Development in Bonn, the European Economic Association 2015 Annual Meeting in Mannheim, and the American Economic Association 2016 Annual Meeting in San Francisco for useful comments. We are particularly grateful to Robert Shiller, Klaus Zimmermann (the editor) and three anonymous referees for extremely helpful suggestions. The views expressed here are of our own and do not necessarily reflect those of the Central Bank of the Republic of Turkey. All errors are ours.
} 


\section{Introduction}

Following the outburst of the Syrian Conflict in March 2011, millions of Syrians have been forced to leave their homes. The conflict has initially generated a huge wave of internal migration within Syria - mostly toward the Turkish, Lebanese, and Jordanian borders. After the sharp increase in the intensity of conflict in late 2011, the internal migration wave has changed nature and transformed into a wave of refugees flowing into the neighboring countries. According to the United Nations (UN) figures, the total number of Syrian refugees in Turkey has reached 1.6 millions as of September 2014 $!^{1}$ The unexpected arrival of a large number of refugees due to the Syrian Conflict resembles a natural experiment that generates an almost exogenous flow of immigrants, which offers a good opportunity to study the economic impact of immigration on the host country. One particular channel through which the inflow of a large number of immigrants within a relatively short period of time can affect the host country is the purchasing power of natives. Our main goal in this paper is to exploit this natural experiment to analyze the impact of Syrian immigrants on consumer prices in Turkey $\left.\right|^{2}$ In particular, we compare the pre- and post-immigration prices in the refugee-receiving regions, with pre- and post-immigration prices in many alternative control regions within a differencein-differences setting. We do not directly observe refugees or their consumption baskets; we, instead, difference out the changes in prices for all CPI items for treatment and control regions.

The advantage of this natural experiment is that both the immigration decision and the location choice within Turkey are mostly exogenous to the refugees' preferences [Tumen (2016)]. The immigration decision is driven by the Syrian Conflict, which forced Syrians to leave their homes within a short period of time. The refugee-sending areas are very close to the SyrianTurkish border. The cities of origin and the corresponding refugee ratios among the entire population of refugees in Turkey is as follows: Aleppo (36\%), Idlep (21\%), Raqqa (11\%), Lattika (9\%), Hassakeh (5.4\%), Hama (7.5\%), and other provinces (10\%). This pattern provides some rough evidence that Syrians caught under fire are forced to cross the nearest border $3^{3}$

\footnotetext{
${ }^{1}$ This figure includes the estimated number of unregistered refugees. For the latest numbers and more detailed statistical information about the Syrian refugee crisis, see the United Nations website http://data.unhcr.org/syrianrefugees/regional.php

${ }^{2}$ See Tumen (2015) for the use of natural experiments in migration research.

${ }^{3}$ See AFAD (2013) for much more detailed descriptive statistics about the Syrian refugees in Turkey. Our companion paper
} 
The location choice within Turkey is mostly driven by the location of accommodation camps constructed by the Turkish government in cities close to the Syrian border. Although some of the refugees have left southeastern Turkey and moved toward the western regions of the country, the refugee to native population ratios are still small in regions with no nearby accommodation camps. Based on a report published by the Turkish Disaster and Emergency Management Presidency (AFAD), around 75-80 percent of the refugees were living out of the government-operated accomodation camps as of 2013 But, a great majority of those living out of camps chose to stay close to camps to benefit from health, education, food, and other basic public services provided by the Turkish government for free. A significant fraction of the ones living out of camps reported that they left their homes for security reasons and they chose Turkey because of the ease of transportation and proximity to home. The refugees are not allowed to work formally (i.e., as a worker registered to the social security system) $!^{5}$ However, they supply inexpensive labor in the informal market. Ceritoglu, Gurcihan Yunculer, Torun, and Tumen (2015) show that the impact of Syrian refugees on the labor market operates through the informal employment channel: informal native workers have been partly substituted by refugees. Specifically, they show that the informal employment-to-population ratio among natives has declined in the refugee-hosting area by 2.2 percentage points and those who left their informal jobs have either left the workforce or remained unemployed. This finding will facilitate the interpretation of the results we document in this paper.

There are three different theories about the impact of immigration on the level of consumer prices [Zachariadis (2012)]. The first one says that immigration generates a jump in the level of aggregate demand; therefore, prices of goods and services should increase as a consequence

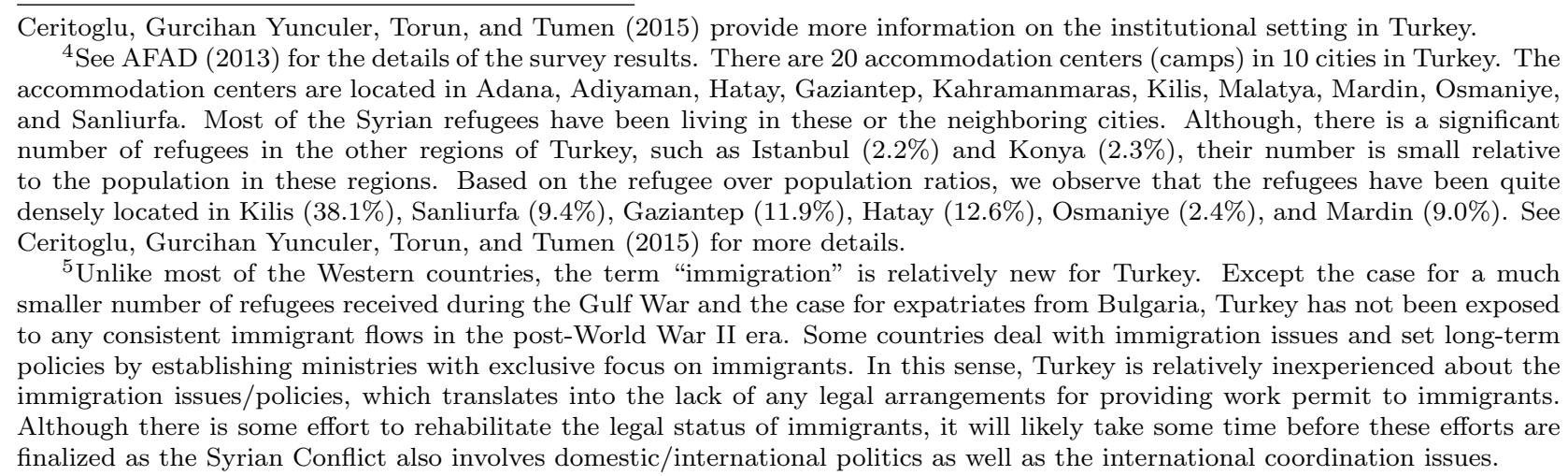


of immigrant inflows. The second one says the opposite. Assuming that the labor market attachment levels of immigrants are lower than those of natives, immigrants will have less time constraints and, thus, they will search for lower prices more intensively. In other words, they will be more sensitive to price differentials (i.e., they will have higher price elasticities). Higher price elasticity, joined with higher search intensity, strengthens the competitive pressure over firms, which will eventually lead to price reductions in the regions hosting immigrants. Finally, if the labor market attachment levels of immigrants are not so low and if immigrants have lower reservation wages than natives due to various well-known reasons listed in the literature, then the resulting labor-cost advantage in the immigrant labor intensive sectors coupled with competitive pressures may lead to price reductions in these sectors relative to the native labor intensive sectors.

Three important papers in the literature test the relevance of these alternative theories. Lach (2007) uses massive immigrant flows from Russia to Israel in 1990 as a natural experiment to estimate the impact of immigration on prices. He finds that a one percentage point increase in the immigrant-to-native ratio leads to a 0.5 percentage point decline in consumer prices. Based on the observation that labor market involvement rates are low among immigrants, he interprets the decline in prices as evidence of higher price elasticities and lower search intensities among immigrants. Cortes (2008) exploits the variation in the flow of low-skill immigrants into several U.S. cities over time to estimate the impact of immigration on consumer prices from a long-term perspective. She finds that a 10 percent increase in the fraction of immigrants leads to 2 percent reduction in the prices of immigrant-intensive services such as housekeeping, gardening, babysitting, and dry cleaning. She argues that an increase in the supply of low-skill immigrants bids down wages in the market for low-skill workers, which generates a cost advantage in the immigrant-intensive sectors, and, thus, leads to a reduction in prices. Finally, Zachariadis (2012) uses cross-country data for the 1990-2006 period and shows that a 10 percent increase in the share of immigrant workers in total employment decreases the prices of final products by approximately 3 percent 6 He focuses on the prices of basic food items that immigrants are more likely to consume and on the prices of basic services that they

\footnotetext{
${ }^{6}$ See also Zachariadis (2011).
} 
are more likely to produce. He documents that the decline in the prices of basic food items is somewhat larger than the change in the price of the "average item," while the prices of basic services decline slower than the price of the "average item." Thus, Zachariadis (2012) argues that both demand- and supply-side explanations are driving the negative relationship between immigration and prices, while he highlights that demand-side forces are likely stronger than supply-side forces.

Using a difference-in-differences strategy we find that consumer prices have declined in the hosting region as a consequence of refugee inflows - which is consistent with the main consensus in the literature. The magnitude of this decline is approximately 2.5 percent. We document that prices of goods and services have declined in similar magnitudes. We find, on the other hand, significant differences across prices of the items produced in formal labor intensive sectors versus those produced in informal labor intensive sectors. In particular, the decline in prices in the informal labor intensive sectors is around 4 percent, while the impact of immigration on prices is almost zero in formal labor intensive sectors. We argue that informal labor market, which is large in Turkey, offers a mechanism through which the refugee inflows generate price declines. Increase in the supply of informal immigrant workers generates labor cost advantages in the informal labor intensive sectors, and, thus, leads to a reduction in the prices of items produced by these sectors. We confirm that these results are robust using alternative empirical settings.

Our paper is similar to Lach (2007) in the sense that we also rely on a natural experiment generated by an unexpected arrival of a large volume of immigrants, while Cortes (2008) and Zachariadis (2012) deal with non-experimental data sets. The main difference between our paper and Lach (2007) is that, in our paper, the impact of immigration on prices is more likely to operate through low labor costs, because Syrian refugees in Turkey have much lower skill levels than Russian immigrants in Israel; therefore, they are better candidates to be employed as low-wage workers. In this respect, our paper is similar to Cortes (2008); that is, we also focus on a mechanism through which the inflow of low-skill immigrants reduces consumer prices through cost advantages generated in the immigrant-intensive sectors. Zachariadis (2012) fo- 
cuses on cross-country data and, therefore, on the impact of aggregate immigration on relative prices. Similar to Zachariadis (2012), we also perform comparisons along goods-services and luxuries-necessities divides; but, unlike his findings, we do not document meaningfully different results across these categories. Our paper is different from these three papers in that the main underlying force is the existence of informal employment opportunities in Turkey. Although Syrian refugees are not permitted to work officially, the availability of a large informal labor market in Turkey allows them to work in low-wage informal jobs - in exchange for wages much lower than the average low-skill native worker would accept.

In a more recent paper, Akgunduz, van den Berg, and Hassink (2015) aim to estimate the effect of Syrian refugee inflows on various outcomes - including labor market outcomes, food prices, and housing rents - in Turkey. Using a differences-in-differences strategy and regionlevel aggregated food price series, they find that food prices have moderately increased in the refugee-receiving regions relative to the rest of the country. In our paper, we exploit the region-level variation along the entire micro-level price data under the Consumer Price Index. Contrary to Akgunduz, van den Berg, and Hassink (2015) and in line with the papers mentioned above, we document a negative relationship between immigrant flows and prices-both for the overall price level and for food prices. We believe that the micro-level details (in particular, the item-level fixed effects for more than 400 items) provide additional information on the potential forces related to the labor-cost channel highlighted in our paper.

Other than the papers discussed above, there are only a few more papers directly estimating the link between immigration and price changes. Alix-Garcia and Saah (2009) investigate the impact of refugee inflows - from Burundi and Rwanda to Western Tanzania in 1993 and 1994 - on food prices in the hosting region. They show that prices of non-aid food have jumped significantly after immigration, while the change in the prices of aid food has only been negligible. Contrary to the findings reported in our paper - and also to those reported by Lach, Cortes, and Zachariadis - they argue that the aggregate demand channel has been effective. However, they focus on a poor-country context; so, in this sense, their results may not be directly comparable to the results documented in other papers. Bentolila, Dolado, and 
Jimeno (2008) show, using a macro approach, that immigration led to a decline in consumer price inflation in Spain in the 1995-2006 period. So, the consensus is that, other than the aid versus non-aid food discussion for poor countries, there is a negative relationship between immigration and the level of consumer prices.

Our paper can also be linked to the literature using natural experiments (i.e., data on forced immigration or refugee flows) to estimate the impact of immigration on various outcomes. Most of the papers in this literature focus on employment and wage outcomes. Card (1990) exploits the natural experiment provided by the Mariel Boatlift of Cubans to Miami in 1980. He shows that the wave of immigration had virtually zero effect on the labor market outcomes of the existing Miami residents. Hunt (1992) employs a similar strategy for the 1962 Algerian repatriates in France and reports that they had only a negligible effect on the labor market outcomes of natives in France. Carrington and de Lima (1996) find strong adverse effects of 1970 repatriates from Africa to Portugal on both employment and wage outcomes of the natives in Portugal. Friedberg (2001) documents that the exogenous inflow of immigrants from the former Soviet Union to Israel had almost no adverse effects on the labor market outcomes of natives in Israel. Cohen-Goldner and Paserman (2011) find that the impact of these Russian immigrants on wage outcomes in Israel have become visible in the long-run. Mansour (2010) exploits the labor supply shock generated by the Israeli-Palestinian conflict and shows that wages of low-skill workers in Israel have been negatively affected, while the effect on the wages of high-skill workers is statistically insignificant. Glitz (2012) estimates the impact of the collapse of Berlin wall on the labor market outcomes in Germany and finds negative employment effects along with zero wage effects. Using a similar identification strategy to ours, Ceritoglu, Gurcihan Yunculer, Torun, and Tumen (2015) show that the rapid and unexpected inflows of Syrian refugees have generated negative employment outcomes (mostly through the informal employment channel), while the wage effects have been negligible. $]^{7}$

The plan of the paper is as follows. Section 2 summarizes the main properties of our data set

\footnotetext{
${ }^{7}$ There are several other papers focusing on other outcomes exploiting similar natural experiments. Gould, Lavy, and Paser$\operatorname{man}(2009)$ investigate the impact of immigration on long-term educational outcomes. Paserman (2013) estimates the effect of immigration on worker productivity. Maystadt and Verwimp (2014) analyze the welfare effects of forced immigration. Saarela and Finnas (2009) study the long-term effects of forced immigration on mortality rates.
} 
and provides a detailed description of the institutional setting for Syrian refugees in Turkey. Section 3 explains our identification strategy. Section 4 discusses the baseline results and also presents the estimates obtained from auxiliary analyses. Section 5 performs additional robustness exercises. Section 6 concludes.

\section{Data and Facts}

\subsection{Details about Syrian Refugees in Turkey}

There has been a massive flow of refugees from northern Syria toward the southeastern regions of Turkey following the civil conflict in Syria. Syrians residing in the troubled regions moved toward the nearest border and were accepted in the neighboring countries, including Turkey, Lebanon, and Jordan, as refugees. Those accepted by Turkey mostly came from the regions geographically close to the Syrian-Turkish border. Figure (1) demonstrates the dramatic increase in the number of Syrian refugees in Turkey over time. Before 2012, there was virtually no Syrian refugees in Turkey. By the end of 2014, the number of registered refugees has reached to almost 1.2 millions and the process is still ongoing. Considering the unregistered ones, the total number of Syrian refugees in Turkey is estimated to be close to 2 millions. The refugees were initially accommodated in the centers or camps constructed and controlled by the Turkish government. There is also a large number of refugees living outside of the camps. But, although they live outside of the camps, they prefer to stay close to camps for the purpose of benefiting from the health, education, food, and other basic services provided by the Turkish government for free. The government-operated accommodation centers are located in Adana, Adiyaman, Hatay, Gaziantep, Kahramanmaras, Kilis, Malatya, Mardin, Osmaniye, and Sanliurfa - there are 20 camps in these cities 8

We observe that most of the Syrian refugees are clustered in these cities or the neighboring ones due to two main reasons: (1) These cities are close to Syria and they hope to go back home easily once the civil conflict is resolved. Surveys conducted in the region confirm the validity of this motive. (2) Cities in which the government-operated camps are located also offer

\footnotetext{
${ }^{8}$ See Figure $\sqrt{2}$ for the exact location of these cities on the map.
} 
government-supported education, health-care, child-care, social/psychological support, and monetary aid. So, the existence and generosity of these amenities also provide incentives for the refugees to stay clustered in the Southeastern Turkey. The refugees are densely located in Kilis, Sanliurfa, Gaziantep, Hatay, Osmaniye, and Mardin - the respective refugee-population ratios are 38 percent, 9.5 percent, 12 percent, 12.5 percent, 2.5 percent, and 9 percent.

Syrian refugees do not have work permit - as of December 2014. However, surveys conducted by governmental aid organizations indicate that most of the refugees are willing to be employed informally and are actively searching for jobs. The rate of informal employment is high, especially in the southeastern Turkey, which means that there are extensive informal employment opportunities for refugees. Based on the figures presented by Ceritoglu, Gurcihan Yunculer, Torun, and Tumen (2015), the informal employment to population ratio is around 0.2 in southeastern Anatolia. The formal employment to population ratio, on the other hand, is around 0.19 . For the entire country, the corresponding ratios are approximately 0.14 and 0.33 for informal and formal employment, respectively. This suggests that the informal labor market is huge in the refugee-receiving regions and offer many informal employment opportunities for the Syrian refugees. The observed characteristics of the Syrian refugees are, on average, quite similar to the Turkish natives living in the hosting region. The gender composition among the refugees is more or less balanced. They have low education levels. Only around 20 percent of the refugees have high school education or above. Most of the refugees are in the age group $19-549$

\subsection{Data on Consumer Prices}

For consumer prices, we use the Turkish Statistical Institute's (TURKSTAT) data set, which is used to calculate the official CPI figures in Turkey. This is a publicly available data set and it is freely accessible from TURKSTAT's web site. In determining the items and weights used to calculate the consumer price index, Target Based Individual Consumption classification (COICOP) is adopted. Based on this classification, expenditures are organized in 44 sub-

\footnotetext{
${ }^{9}$ For more contextual details, see the documentation posted on the website (https://www.afad.gov.tr/en/Index.aspx) of the Turkish Disaster and Emergency Management Presidency (AFAD).
} 
groups and 12 major groups [see Tables (1) and (2)]. Overall, 437 items are used in constructing the index. The prices of goods and services covered by the index are retail prices including taxes but excluding any deposits and installments. The methodology used to calculate the CPI is in line with EUROSTAT's standards. The prices are collected using a sample of around 13,000 households. The index covers the entire population in Turkey without adjusting the weights according to income level or geographical areas. The regional prices are given based on NUTS2-level regional categorization. There are 81 cities in Turkey and these cities are grouped into 26 NUTS2-level regions. We can only observe prices at the NUTS2 level, not at the city level.

To determine which sectors have high informal labor intensities, we use the Turkish Household Labor Force Survey micro-level data sets for the period 2010-2011-i.e., for the preimmigration period. This data set is also compiled by TURKSTAT and is used to construct the official employment statistics in Turkey. There are 87 sectors (or industries) classified at the two-digit level based on NACE-Rev2. The survey also asks whether the worker is registered with the social security authority in his/her current job or not. If the worker is not registered, we classify him/her as an informal worker. Using information on informal employment and sector of employment, we determine the level of informal labor intensity in each sector for the treatment region. More precisely, we call a sector "informal labor intensive" if more than 50 percent of all workers employed in that sector are informal workers. We then match the consumption items with the sector information to analyze whether the price changes emanate from informal labor intensive sectors or not. It should be noted that we do not make any claim about "labor intensity" versus "capital intensity" of these sectors, which is out of the scope of the current paper. We only calculate the ratio of the number of informal workers to all workers in each sector and mark the sectors above 0.5 as "informal labor intensive sectors."

\section{$3 \quad$ Empirical Strategy}

In this section, we discuss the details of our identification strategy. The ultimate goal is to estimate the causal impact of immigration on the level of consumer prices in the hosting 
regions. It is well-known that the non-experimental immigration data typically suffer from selectivity problems [Borjas (1987, 1994), Borjas, Bronars, and Trejo (1992)]. One way to deal with the self-selection problem is to rely on immigration cases that generate "forced" movements across borders. By this way, immigrants will not self-select themselves into a certain country; instead, they will be forced to move from one country to the other based on reasons orthogonal to their country preferences. The movement of refugees from northern Syria to southeastern Turkey offers a suitable setting in which one can design a quasi-experimental estimation strategy.

The validity of the quasi-experiment in our case relies on the following four conditions: (1) the immigration wave should be generated by external forces, (2) the location of the immigrants within the hosting country should also be driven, at least partially, by external forces, (3) immigrant flows should not generate a wave of internal migration of natives from immigrantintensive areas toward other areas in the country, and (4) absent immigration, the changes in demand between treatment and control regions would have been the same. The first condition is satisfied by nature. The civil conflict in Syria has been severe and Syrians in the affected regions had no choice but to move toward the nearest border. Countries including Turkey, Lebanon, and Jordan received a massive number of refugees. The institutional setting in Turkey also generated an almost exogenous location choice within Turkey, which confirms the validity of the second condition. Government-operated accommodation camps have been constructed in the southeastern part of Turkey. Almost all of the registered Syrians are located in these camps. There is also a quite large amount of unregistered immigrants. However, most of them also choose to live in the cities with accommodation camps, because the Turkish government provides education, child-care, health-care, social, and monetary support to immigrants in these cities. The existence of these camps increases the appeal of these cities for the unregistered immigrants. The government, on the other hand, chooses the location of the camps solely based on proximity to major source cities in Syria. So, the clustering of Syrian refugees in Turkish cities also relies mostly on exogenous factors. Third, we also observe that there is currently no sign of a flow of natives from the hosting regions toward regions with no 
immigrants. Based on the Turkish Statistical Institute data showing the patterns of internal migration, we observe no significant change in the internal migration patterns in the postimmigration era relative to the pre-immigration era. In Section 5, we provide some empirical evidence supporting this observation. Finally, we perform some auxiliary analyses - using two different proxies for regional demand conditions - to show that there is no sign of a change in aggregate demand conditions in the treatment region as a consequence of the refugee inflow. The results of these auxiliary exercises are also presented in Section 5. At the end, we conclude that our setting is suitable for implementing quasi-experimental techniques ${ }^{10}$

We use a difference-in-differences (DID) approach to estimate the impact of immigration on prices. There is a "treatment region" versus a "control region" and a "pre-immigration period" versus a "post-immigration period." Figure (2) presents a visual display of our treatment and control regions. Our data set does not allow us to see the city-level details. Instead, we can observe the price data for regions at the NUTS2-level detail. There are 81 cities in Turkey and they are grouped under 26 NUTS2-level regions. Our treatment region consists of five NUTS2-level regions, which are the regions with high immigrant concentration. The cities in the treatment area include Kilis, Osmaniye, Gaziantep, Kahramanmaras, Sanliurfa, Batman, Diyarbakir, Adiyaman, Sirnak, Siirt, Adana, Mardin, Hatay, and Mersin. These cities are indicated with green color on the map. There is a certain degree of heterogeneity within the treatment region in terms of immigrant concentration. It should be noted that cities with low immigrant concentration, such as Diyarbakir, Siirt, and Sirnak, are included due to the restriction that we can only observe region-level rather than city-level geographical details. Still, for all cities in the treatment region, the immigrant to population ratio is above 0.2 percent - it goes up to 40 percent in Kilis. The control area, on the other hand, consists of four regions indicated with pink color on the map. The immigrant to population ratio is virtually zero in the control region. The cities in the control area are Erzurum, Erzincan, Elazig, Malatya, Mus, Van, Kars, Ardahan, Agri, Igdir, Hakkari, Bingol, Tunceli, Bayburt, and Bitlis.

\footnotetext{
${ }^{10}$ Another concern might be related to the existence of "daily migration" of workers between regions. We do not have data to convert this concern into a directly measurable variable, but our observation is that work-oriented daily migration is not a common practice in Turkey. Moreover, our regional classification is broad, i.e., the NUTS2-level classification places several cities in each region. In addition, the distances between the cities/regions are quite large. So, the existence of any systematic daily migration pattern (to the extent that can contaminate our estimates) is a highly unlikely scenario.
} 
The treatment and control areas are very close to each other in terms of geographical location, cultural background, social norms and attitudes, and the level of economic development 11 In this sense, our research design is quite similar to Card and Krueger (1994), who investigate the impact of a change in the minimum wage law in New Jersey on employment outcomes by performing a comparison across the fast food restaurants among New Jersey and Eastern Pennsylvania. The main identifying assumption is that the two regions are close to each other geographically and similar in many other respects. Ceritoglu, Gurcihan Yunculer, Torun, and Tumen (2015) show that our treatment and control regions are quite similar to each other in terms of prior trends in labor market outcomes. We provide evidence that the prior trends in price changes also exhibit similar patterns. In other words, the prices in the treatment and control regions follow very similar trends prior to refugee inflows [see Figure (3)]. In Section 5 , we try alternative control regions to address the concern that the results may be driven by the choice of the control region and provide strong evidence that our estimates are robust to using alternative control regions.

As we indicate above, there is also a divide among pre-immigration versus post-immigration periods. Figure (1) suggests that the refugee inflows have started after January 2012. Before this date, the immigrant flow was basically nil. Taking January 2012 as the cutoff point, we construct a window that sets $2010-2011$ as the pre-immigration period and 2012-2014 as the post-immigration period. Our identification strategy aims at estimating the impact of immigration on the consumer prices in the hosting region by comparing the pre- and postimmigration outcomes in the treatment versus control regions. To achieve this goal, we construct a dummy variable $T$ taking 1 in the treatment region, 0 in the control region and another dummy variable $P$ taking 1 in the post-immigration period, 0 in the pre-immigration period. This structure implies the following DID equation:

$$
\ln p_{i, r, y, m}=\delta+\beta \cdot\left(T_{i, r} \times P_{i, y}\right)+f_{i}+f_{r}+f_{y}+f_{m}+\epsilon_{i, r, y, m},
$$

\footnotetext{
${ }^{11}$ To have an idea about the goodness of the control group, see Ceritoglu, Gurcihan Yunculer, Torun, and Tumen (2015) for detailed information on both the demographic characteristics of the natives residing in the control versus treatment areas and the development/labor market indicators of the control versus treatment regions.
} 
where $i, r, y$, and $m$ index items, regions, years, and months, respectively, $\ln p$ is the natural logarithm of the item price, and $f_{i}, f_{r}, f_{y}$, and $f_{m}$ are item-level, region-level, year-level, and month-level fixed effects. The parameter $\beta$ gives the average impact of immigration on prices in the treatment region in log-point terms. In our estimations, we use three different productclass categories, so the interpretation of $f_{i}$ will be different in each of these three cases. See the next section for details.

\section{Results and Discussion}

\subsection{Main Findings}

We begin by describing the impact of immigration on the overall price level in the hosting regions. To understand the potential mechanisms, we further refine our analysis by conditioning the regressions on certain sub-groups of items. First, we perform separate regressions for goods and services. Cortes (2008) suggests that production of services is more likely to be immigrant-intensive; therefore, labor-cost advantages in the production of services could generate important reductions in the prices of services relative to the prices of goods. Second, we perform separate regressions for formal labor intensive and informal labor intensive sectors. Ceritoglu, Gurcihan Yunculer, Torun, and Tumen (2015) find that Syrian refugees substitute out natives in the informal labor market. If this channel is effective, then the prices of items produced in the informal labor intensive sectors will decline relative to those produced in the formal labor intensive ones. Finally, we perform separate regressions for 12 broad product categories to detect the ones on which the effect of immigration has been most prevalent. To make our estimates consistent with the weights of items in the consumption basket in Turkey, we use CPI weights in our regressions. Standard errors are clustered with respect to the month of observation to capture the possibility that there might be month-specific correlations in price changes 12

\footnotetext{
${ }^{12}$ It is well-known that the standard errors of a difference-in-differences estimator may be underestimated (and, therefore, may lead to overestimated statistical significance) if the potential serial correlation issues are not appropriately controlled for [see, e.g., Moulton (1986) and Mullainathan, Bertrand, and Duflo (2004)]. To avoid this problem, we clustered the standard errors by month, item, region, region-month, item-month, and item-region. We also tried the block bootstrap method. Among all of these alternatives, clustering the standard errors by the month of observation gave us the most conservative standard errors - consistently across specifications. Accordingly, we clustered the standard errors by the month of observation.
} 
Table (3) presents the results for the overall prices. There are 437 items in our data set and we have 216,932 price observations for these items. As we describe in Section 2, we make three categorizations consistent with the formal definitions of items in the CPI basket. The first one groups the items under 12 broad product classes. The second one forms 44 product classes. The third one does not impose any grouping across items. Column [1] controls for fixed effects for 12 (broad) product classes, column [2] controls for product-class fixed effects for 44 (narrower) categories, and column [3] controls for 437 item-level fixed effects. We find that Syrian refugee inflows have led to a decline in the overall level of prices and this result is robust to alternative product-class categorizations and the inclusion of the corresponding fixed effects. For the finest categorization-i.e., when we include 437 item-level fixed effects-we find that immigration has reduced prices, on average, by around 2.5 percent. This number is consistent with the range of estimates reported in the related literature.

Table (4) reports the results of the regressions for only goods - excluding services. There are 340 items that are classified as goods and we observe 166,926 prices for these goods. Similar to Table (3), we report the estimates for 3 different product categorizations. The results for goods are quite similar to the results from the overall regressions. In particular, we find that, controlling for 340 item-level fixed effects, immigration has reduced prices of goods by approximately 2.6 percent in the hosting region relative to the control region. Table (5) presents the estimates for services only. There are 97 items and 50,006 price observations for these items in our sample. We find that, controlling for 97 item-level fixed effects, the reduction in services is around 2.2 percent. Although the estimates for services are slightly lower than the estimates for goods, the economic significance of this difference is low. We conclude that the overall reduction in prices due to immigration is driven almost equally by goods and services. This is different from the results presented by Cortes (2008), who finds that prices are more likely to be reduced for non-traded goods and services because production is heavily immigrant-intensive in these sectors. Our findings suggest that goods and services are almost equally affected by refugee inflows; in fact, the reduction in the prices of goods is slightly larger than the reduction in the prices of services. 
Ceritoglu, Gurcihan Yunculer, Torun, and Tumen (2015) find that the inflow of Syrian refugees has negatively affected the employment outcomes of natives residing in the hosting regions. They further show that the negative employment effects mostly consist of employment losses in the informal labor market. In particular, they report that around 10 percent of the informal native workers have been displaced from their jobs following the refugee inflows. The Syrian refugees do not have work permit; so, their penetration has become possible through the informal labor market, which is large in Turkey - around 20 percent of all non-agricultural workers are not registered with the social security authority. The rate of informal employment is even larger, close to 50 percent, in the hosting region. Taken at face value, this finding implies that part of the informal workers have been substituted out by Syrian refugees who are willing to work in exchange for a much lower pay than his/her Turkish native counterparts. This would generate a labor cost advantage, and in the existence of competitive forces in the product market, would drive the prices down in the informal labor intensive sectors. To test this hypothesis, we perform separate regressions for the items produced in the informal labor intensive sectors versus the sectors in which the share of informal employment is lower. To determine in which sectors informal workers are mostly employed, we use the Turkish Household Labor Force Survey micro-level data set, which has information on 87 industry categories classified based on the standard NACE-Rev2. Items produced in sectors with 50 percent and more informal employment are marked as informal labor intensive products. See Section 2 for more details on the data.

Table (6) reports the results of the regressions for informal labor intensive items. Based on the description given above, there are 208 informal labor intensive items with 99,871 price observations. We find that the reduction in the prices of those items, after controlling for 208 item-level fixed effects, is around 4 percent. Table (7) repeats the same exercise for products of the formal labor intensive sectors, for which we have 229 items and 117,061 price observations. Our estimates say that the decline in the prices of formal labor intensive items is very close to zero - in the order of 0.4 percent. In other words, the decline in the prices of informal labor intensive items is 10-fold larger than the decline in the prices of formal labor 
intensive ones. These results suggest that the mechanism through which Syrian refugee inflows lead to a decline in the level of prices in the hosting region is related to informal employment. Replacing informal native workers with observationally equivalent immigrants, who are willing to accept much lower wages, would be a rational choice for the firms operating in informal labor intensive sectors. Ceritoglu, Gurcihan Yunculer, Torun, and Tumen (2015) also report that Syrian refugee inflows do not alter the wage outcomes of the natives - both for formal and informal wages. This does not contradict with the mechanism we offer. The informal workers who are more likely to be replaced by low-pay immigrants are $(i)$ the least productive ones (who potentially receive very low wages) and (ii) the low-skill ones who receive high wages. Replacing a combination of the workers from these two groups with observationally equivalent immigrants may not alter the average wages of informal native workers in a statistically significant way. Moreover, anecdotal evidence suggests that the new hires in the informal labor market include a large number of low-cost Syrian refugees. Since the Turkish Household Labor Force Survey does not include the refugees, the new hires are unobserved and the wage regressions do not yield a statistically significant immigration effect.

Finally, to broadly understand the sectors in which the price reductions are most effective, we condition our regressions on the following 12 product categories: food, alcohol and tobacco, clothing and shoes, housing, furniture, health, transportation, communication, recreation, education, hotel and restaurant, and other [see Table (8)]. We find that there are large price declines in food (4.5 percent), hotel and restaurant (5.4 percent), and education (10.5 percent). Production of food, especially fresh fruits and vegetables, and services related hotels and restaurants are highly informal labor intensive. Food, and hotels and restaurants have the largest weight in the consumption basket. So, this result is consistent with the mechanism we offer. For education, the decline is likely not related to informal employment. Government subsidies in the region in the post-immigration era are likely the reason for reduction in prices in the education sector. For other categories, we either see smaller price declines, which are statistically significant, or statistically insignificant small increases. Overall, results from the sub-categories support the role of substitution-driven price reductions in informal labor 
intensive sectors. Next we perform several exercises to check the robustness of our estimates as well as testing the validity of the mechanism we offer.

\subsection{Understanding the Role of Demand Conditions}

Our basic results summarized above suggest that the main mechanism - that reduces consumer prices as a consequence of refugee inflows - is driven by labor-cost advantages generated in the informal labor intensive sectors. It should be noted that, and as we indicate in Section 3, our maintained assumption throughout our basic empirical analysis is that: "absent immigration, changes in aggregate demand conditions between treatment and control regions are the same."

This assumption will be violated under two circumstances: (1) if the aggregate demand in the treatment region increases relative to that in the control region due to refugee inflows and; (2) if the aggregate demand in the treatment region decreases relative to that in the control region due to refugee inflows. In the first case, the increase in the relative demand will push the prices up; therefore, the true price decline due to immigration would be underestimated, which means that our estimates can only be interpreted as a lower bound. The second case is more problematic. A decline in the relative demand will further pull the prices down. Thus, it will be impossible to identify whether the observed decline in prices is driven by the wage-cost channel or the aggregate demand channel.

In this section, we test the relevance of the two cases explained above. We start with the first case, i.e., we test whether the aggregate demand level in the treatment region increases relative to that in the control region. The main idea is that Syrian refugees in Turkey are mostly lowskill/low-income individuals. As suggested by Zachariadis (2012), lower-income immigrant groups are more likely to consume items that can be deemed as "necessities." In other words, if there is a demand-related price increase due to immigration, then this should be clearly observed along the necessity-luxury divide in the sense that we should observe an increase in

the price of necessity items. To perform this test, we run our basic DID regressions for necessity and luxury items, separately. Maystadt and Verwimp (2014) argue that the aggregate demand channel operates mostly over the food items. Therefore, we focus on basic food versus luxury 
food items in these supplementary regressions. Table $(9)$ reports the estimates ${ }^{13}$ We find that prices of both the basic and luxury food items decline in the treatment area after immigration. But the price decline is more pronounced for the basic food items than the luxury food items. To be precise, the decline is around 7 percent for the basic food items, while it is around 2 percent for the luxury items. This suggests that the aggregate demand channel may not have a role in pushing the prices up in the refugee-receiving regions ${ }^{14}$

Next, we perform the opposite task; i.e, we test whether the aggregate demand level in the treatment region decreases relative to that in the control region. One way through which such a channel can operate is the internal migration of natives. If natives living in the refugee-receiving regions choose to move into regions with no refugee population, then aggregate demand will fall in the treatment region and rise in the control region; at the end, the difference-in-differences strategy will yield a price decline in the treatment region. We take the year-by-year and city-by-city internal migration data from TURKSTAT, and implement our baseline difference-in-differences idea over this data set to test whether refugee flows have triggered a change in the patterns of internal migration across our treatment and control regions - similar to Akgunduz, van den Berg, and Hassink (2015). Table (10) provides the estimates for the internal migration regressions. We find that for the in-migration, out-migration, and net-migration outcomes, the regressions yield coefficients which are not statistically significant. Note that setting the Eastern Anatolia as the control region is particularly appropriate in this context, because there are huge cities (such as Istanbul, Ankara, Izmir, and Bursa) in the rest of the country which consistently and heavily receive internal immigrants, while the cities in the treatment area typically suffer from out-migration of natives. In this sense, the cities in Eastern Anatolia are quite similar to the cities in the treatment region.

\footnotetext{
${ }^{13}$ We list the basic and luxury food items below Table 9 . The constant terms in the regressions demonstrate the large price differentials between basic versus luxury food items.

${ }^{14}$ The result that prices of basic foods decline much faster than the prices of luxury foods may have an alternative interpretation. Immigrant flows may affect demand conditions both through shifting the level of aggregate demand and generating a change in the composition of aggregate demand. If immigrants have lower opportunity cost of time than natives, then they may search for low prices more intensively than natives. Moreover, the price search activity of immigrants may be more intensive for basic food items than luxury food items. As a result, a price-search mechanism may also be operating in the background. It should be noted that basic food items are likely produced via a more informal labor intensive technology than luxury food items. So, our findings along the basic versus luxury food divide can also be interpreted as an evidence favoring the informal labor market channel that we propose in this paper. But there is no easy way of separately identifying these two potential forces given the data at hand.
} 
Another channel through which aggregate demand can decline is the direct effect of the "Syrian Conflict" itself on the level of economic activity in the refugee-receiving regions in Turkey. Unfortunately, there is no region-level GDP or production data in Turkey, so it may not be possible to perform an analysis with "direct" measures of economic activity. One indirect proxy for regional economic activity, however, can be the region-level international trade data. This is a particularly good proxy, because the refugee-receiving regions are close to the Syrian border and a considerable volume of economic activity in these regions is related to trade relationships with Syria and Middle Eastern countries. If the Syrian Conflict has led to a decline in trade volume in the treatment region, then one should expect to see negative and statistically significant coefficients in a difference-in-differences regression-similar to our baseline specifications - performed using region-level international trade data. Table (11) documents the estimates for exports and imports, separately. Monthly TURKSTAT trade volume data is used at the city level and the treatment versus control groups are defined similar to our baseline estimations. The regressions yield statistically insignificant estimates in all specifications, which suggests that the refugee crisis does not have an impact on the volume of international trade in the treatment region relative to the control region. To the extent that the international trade volume can proxy the level of economic activity, these results also suggest that the refugee crisis does not have any impact on aggregate demand through its direct effect on the level of economic activity.

\section{Robustness Checks}

We perform four different robustness exercises. The first one exploits the time variation in the stock of refugees in Turkey. The second one uses alternative control regions to address the concern that the choice of the control group in our original analysis might be driving the results. The third one exploits the variation in the refugee intensity across the refugeereceiving regions to see if the results change as a function of refugee intensity. The last one sets placebo dates for the start of the refugee inflows.

Our first robustness exercise exploits the increase in the stock of refugees over time for the 
purpose of detecting whether the estimates reported in the previous section should indeed be interpreted as the impact of immigration on prices. Figure (1) says that the refugee inflows have become larger over time. Thus, if our estimates are indeed associated with immigration, then we should obtain only a small negative estimate when we set 2012 as the post-immigration period. When we condition separately on 2013 and 2014, on the other hand, we should obtain substantially larger estimates than 2012. Moreover, the estimate for 2014 should be even larger than the estimate for 2013. Also, the role of the informal employment channel should become clearer as we move from 2012 to 2014. Two forces may be driving this result. First, the rapid increase in the number of refugees over time might be reinforcing the negative impact of immigration on prices. Second, the level of labor market attachment among refugees might be going up over time, which may generate amplified price effects.

To test these insights, we repeat our baseline analyses by setting the post-immigration period as 2012, 2013, and 2014 in separate regressions. Table (12) reports the results of three exercises and confirms all the insights mentioned above with great clarity. Panels $A, B$, and $C$ separately set 2012, 2013, and 2014 as the post-immigration period, respectively. The preimmigration period is 2010-2011 in all three regressions. Since we use item-level fixed effects in all regressions, the results are comparable to the results given in column [3] of Table (3). The results suggest that the decline in prices were only 1.5 percent in 2012 , while it became 2.7 and 3.2 percent in 2013 and 2014, respectively. This means that the negative impact of immigration on prices became more pronounced as the number of Syrian refugees in Turkey went up. The mechanism that we propose - that price decreases are realized through labor cost advantages generated in sectors with high informal labor intensity - is also strongly supported by the results of this robustness exercise. The decline in prices for the products of the sectors with high informal labor intensity is estimated as 2 percent, 4.2 percent, and 5.1 percent for 2012, 2013, and 2014, respectively. In all three years, almost the entire effect comes from the informal labor intensive sectors.

The second robustness exercise fixes the treatment region and uses alternative control regions. Our original control region includes the cities in eastern Anatolia, which are similar to the cities 
in the treatment region in terms of cultural, demographic, and socio-economic characteristics. One can argue that the choice of the control region might be driving our results. To address this concern, we replace our original control region with two alternative regions. The first one is the entire country excluding the treatment region. Table $(13)$ reports the results of the regression in which we replace the original control region with this alternative control region. The results are mainly the same, although the magnitudes are a bit smaller. On aggregate, the prices have declined by 1.7 percent. Again, the decline has been driven by the sectors, which intensively rely on informal workers. To be precise, the prices have declined by around 2.7 percent in informal labor intensive sectors, while the price changes are almost equal to zero in formal labor intensive sectors.

The second alternative control region is defined as entire country excluding the treatment region and the original control region. The purpose of this second exercise is to entirely exclude the original control region from the analysis. Table (14) documents the results. The results are almost unchanged. Our main observation is that, although the estimates are a bit smaller than the original estimates, the results of these robustness exercises confirm the validity of the qualitative nature of our baseline results.

The third exercise exploits the variation in the number of refugees within the treatment region. Figure (2) documents the extent of this variation. In this robustness exercise, we exclusively focus on the sub-regions within the original treatment region. If we set each sub-region as a different treatment region and perform our baseline difference-in-differences analysis, then we should see a larger impact for the regions with greater refugee intensity and a smaller impact for the regions with more modest refugee intensity. Such a picture will enhance our conclusion that the observed price effect may indeed be attributed to refugee inflows. Table (15) reports the estimates for each of the five NUTS2-level sub-regions listed in our broad treatment region. The table also reports the average refugee-to-population ratios within each sub-group. The estimates clearly suggest that the price declines tend to be larger in regions with greater refugee intensity. It might also be useful to state the estimates in terms of elasticities. Using the estimates reported in Table $(15)$, it is possible to perform some back- 
of-the-envelope calculations to obtain an elasticity estimate. Our calculations suggest that, at the NUTS2-level, a 10 percentage-point increase in the refugee to population ratio generates 2.2 percent decline in consumer prices. This magnitude is comparable to the typical estimates reported in the literature.

Finally, we set 2011 as the placebo treatment date, as if the refugee inflows started in January 2011 rather than January 2012. We expect to see no price effect in this placebo exercise. The results reported in Table (16) suggest that setting January 2011 as the placebo treatment date instead of January 2012 yields small and statistically insignificant coefficients, which again supports the validity of our estimates.

\section{Concluding Remarks}

Most of the migration research investigate the link between the intensity of immigration and the labor market outcomes of natives. The main reason is that labor market outcomes are directly related to the purchasing power and, therefore, the welfare levels of the natives residing in the hosting regions. Another important channel, which is often neglected, that can directly affect the purchasing power of natives is the level of consumer prices and immigration may lead to a change in the level of prices in the hosting region through several mechanisms. First, immigration may increase the aggregate demand in the hosting region, so it can shift the prices up. Second, immigrants might be the ones with less stringent time constraints than natives; so, if this is the case, then immigrants will have more time to search for lower prices, which will decrease prices of consumption goods in the hosting region. Finally, new immigration can reduce the level of prices for the items produced in the immigrant labor intensive sectors, since arrival of immigrants will likely generate labor cost advantages in these sectors. There is a consensus in the literature that immigration likely leads to a reduction in consumer prices in the hosting region, but the mechanism through which these price declines take place is still an open question.

In this paper, we exploit the forced immigration from Syria to Turkey, due to civil conflict 
in Syria, as a natural experiment to estimate the causal effect of immigration on the level of consumer prices. Our findings confirm that immigration is associated with consumer price declines and the magnitude of this decline is around 2.5 percent, on average. We also find strong evidence supporting the relevance of the labor-market channel. Syrian refugees are more willing to accept lower pay relative to the natives residing in the region. Labor cost advantages generated in the sectors in which immigrants are employed reduce the prices of goods and services produced in these sectors. We identify a particular channel through which the labor cost advantages take place: informal employment. Syrian refugees do not have work permit. However, informal employment is prevalent in Turkey and the rate of informal employment is particularly high in the hosting region. The existence of informal employment opportunities facilitates the diffusion of Syrian refugees into the Turkish labor markets. So, if this is a relevant channel, then we should observe significant price reductions in the informal labor intensive sectors in the hosting region in the post-immigration era. We show that price reductions almost exclusively come from the sectors heavily relying on informal workers. We conclude that Syrian refugees substitute out informal native workers in sectors with high informal labor intensities. This substitution generates labor cost advantages and, in combination with competition in the product markets, leads to reductions in consumer prices. 


\section{References}

AFAD (2013): "Syrian Refugees in Turkey, 2013: Field Survey Results," Turkish Disaster and Emergency Management Presidency.

Akgunduz, Y. E., M. van Den Berg, and W. Hassink (2015): "The Impact of Refugee Crises on Host Labor Markets: The Case of the Syrian Refugee Crisis in Turkey," IZA Discussion Paper No: 8841.

Alix-Garcia, J. And D. SAAH (2009): "The Effect of Refugee Inflows on Host Communities: Evidence from Tanzania," World Bank Economic Review, 24, 148-170.

Bentolila, S., J. J. Dolado, And J. F. Jimeno (2008): "Does Immigration Affect the Phillips Curve? Some Evidence for Spain," European Economic Review, 52, 1398-1423.

BorJas, G. J. (1987): "Self-Selection and the Earnings of Immigrants," American Economic Review, 77, 531-553. (1994): "The Economics of Immigration," Journal of Economic Literature, 32, 16671717.

Borjas, G. J., S. G. Bronars, and S. J. Trejo (1992): "Self-Selection and Internal Migration in the United States," Journal of Urban Economics, 32, 159-185.

CARD, D. (1990): "The Impact of the Mariel Boatlift on the Miami Labor Market," Industrial and Labor Relations Review, 43, 245-257.

Card, D. And A. B. Krueger (1994): "Minimum Wages and Employment: A Case Study of the Fast-Food Industry in New Jersey and Pennsylvania," American Economic Review, 84, 772-793.

Carrington, W. J. And P. J. F. de Lima (1996): "The Impact of 1970s Repatriates from Africa on the Portuguese Labor Market," Industrial and Labor Relations Review, 49, $330-347$.

Ceritoglu, E., H. B. Gurcihan Yunculer, H. Torun, and S. Tumen (2015): "The Impact of Syrian Refugees on Natives' Labor Market Outcomes in Turkey: Evidence from 
a Quasi-Experimental Design," Unpublished manuscript, Central Bank of the Republic of Turkey.

Cohen-Goldner, S. And D. M. Paserman (2011): "The Dynamic Impact of Immigration on Natives' Labor Market Outcomes: Evidence from Israel," European Economic Review, 55, 1027-1045.

Cortes, P. (2008): "The Effect of Low-Skilled Immigration on U.S. Prices: Evidence from CPI Data," Journal of Political Economy, 116, 381-422.

FriedBerG, R. M. (2001): "The Impact of Mass Migration on the Israeli Labor Market," Quarterly Journal of Economics, 116, 1373-1408.

Glitz, A. (2012): "The Labor Market Impact of Immigration: A Quasi-Experiment Exploiting Immigrant Location Rules in Germany," Journal of Labor Economics, 30, 175-213.

Gould, E. D., V. Lavy, And D. M. Paserman (2009): "Does Immigration Affect the Long-Term Educational Outcomes of Natives? Quasi-Experimental Evidence," Economic Journal, 119, 1243-1269.

Hunt, J. (1992): "The Impact of the 1962 Repatriates from Algeria on the French Labor Market," Industrial and Labor Relations Review, 43, 556-572.

LACH, S. (2007): "Immigration and Prices," Journal of Political Economy, 115, 548-587.

Mansour, H. (2010): "The Effects of Labor Supply Shocks on Labor Market Outcomes: Evidence from the Israeli-Palestinian Conflict," Labour Economics, 17, 930-939.

Maystadt, J.-F. And P. Verwimp (2014): "Winners and Losers among a Refugee-Hosting Population," Economic Development and Cultural Change, 62, 769-809.

Moulton, B. R. (1986): "Random Group Effects and the Precision of Regression Estimates," Journal of Econometrics, 32, 385-397.

Mullainathan, S., M. Bertrand, And E. Duflo (2004): "How Much Should We Trust Differences-in-Differences Estimates?" Quarterly Journal of Economics, 119, 249-275. 
Paserman, D. M. (2013): "Do High-Skill Immigrants Raise Productivity? Evidence from Israeli Manufacturing Firms, 1990-1999," IZA Journal of Migration, 2, 1-31.

SaArela, J. And F. Finnas (2009): "Forced Migration and Mortality in the Very Long Term: Did Perestroika Affect Death Rates also in Finland?" Demography, 46, 575-587.

Tumen, S. (2015): "The Use of Natural Experiments in Migration Research," IZA World of Labor.

2016): "The Economic Impact of Syrian Refugees on Host Countries: QuasiExperimental Evidence from Turkey," Forthcoming, American Economic Review.

Zachariadis, M. (2011): "Immigration and International Prices: An Initial Assessment," Economics Letters, 110, 83-85.

(2012): "Immigration and International Prices," Journal of International Economics, 87, 298-311. 


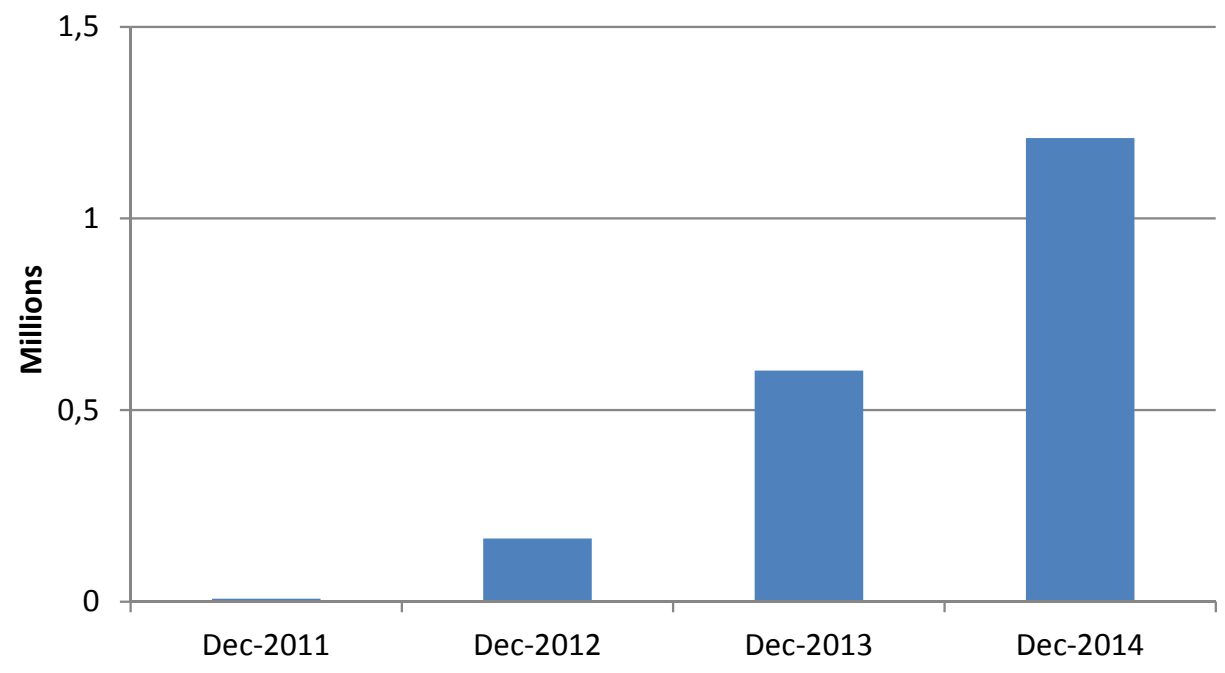

Figure 1: Stock of registered Syrian refugees in Turkey (thousands). Source: UN Refugee Agency, http://data.unhcr.org/syrianrefugees/country.php?id=224.

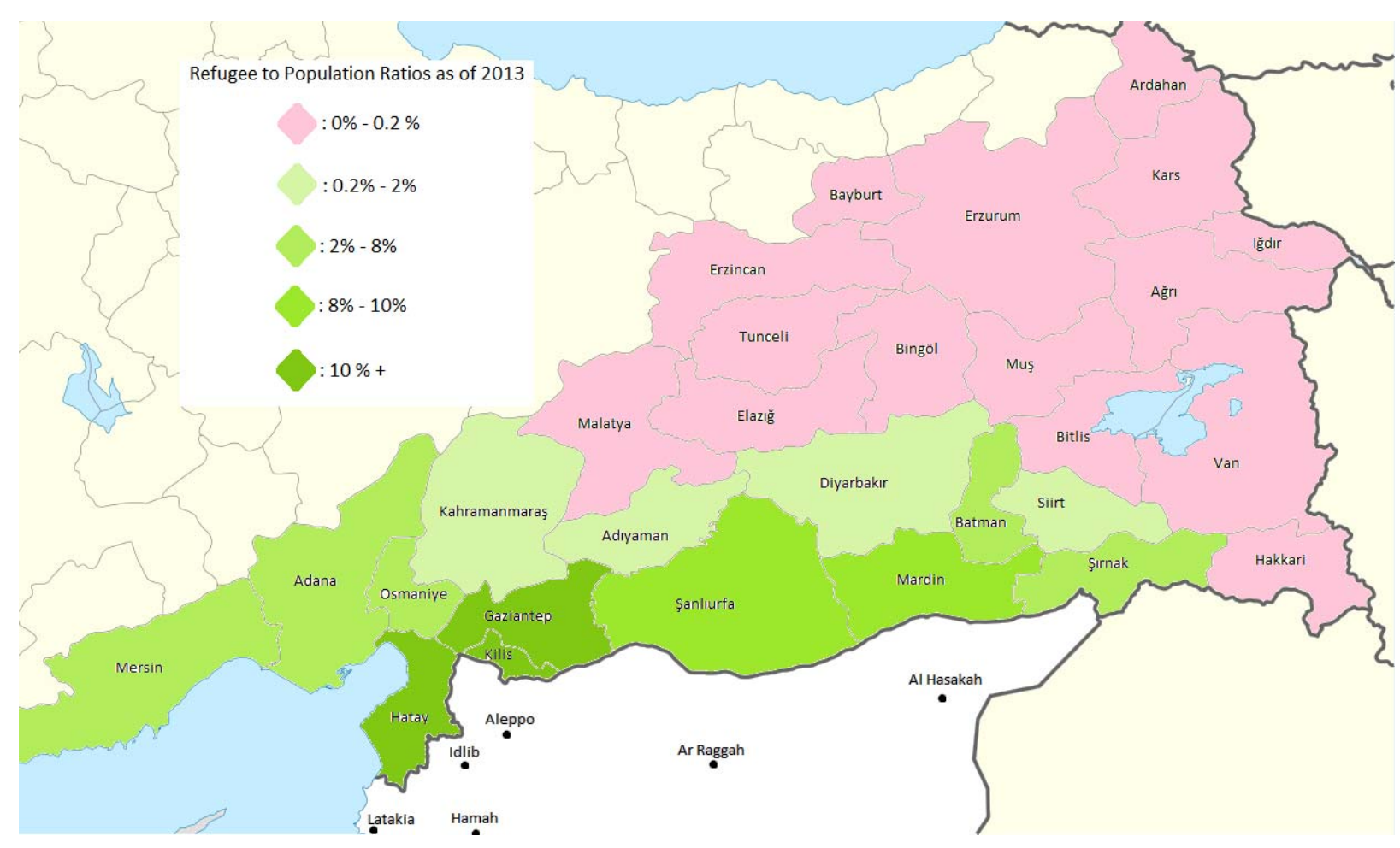

Figure 2: Visual representation of treatment and control regions for our baseline scenario. The green area is the treatment region, while the pink area is the control region. 


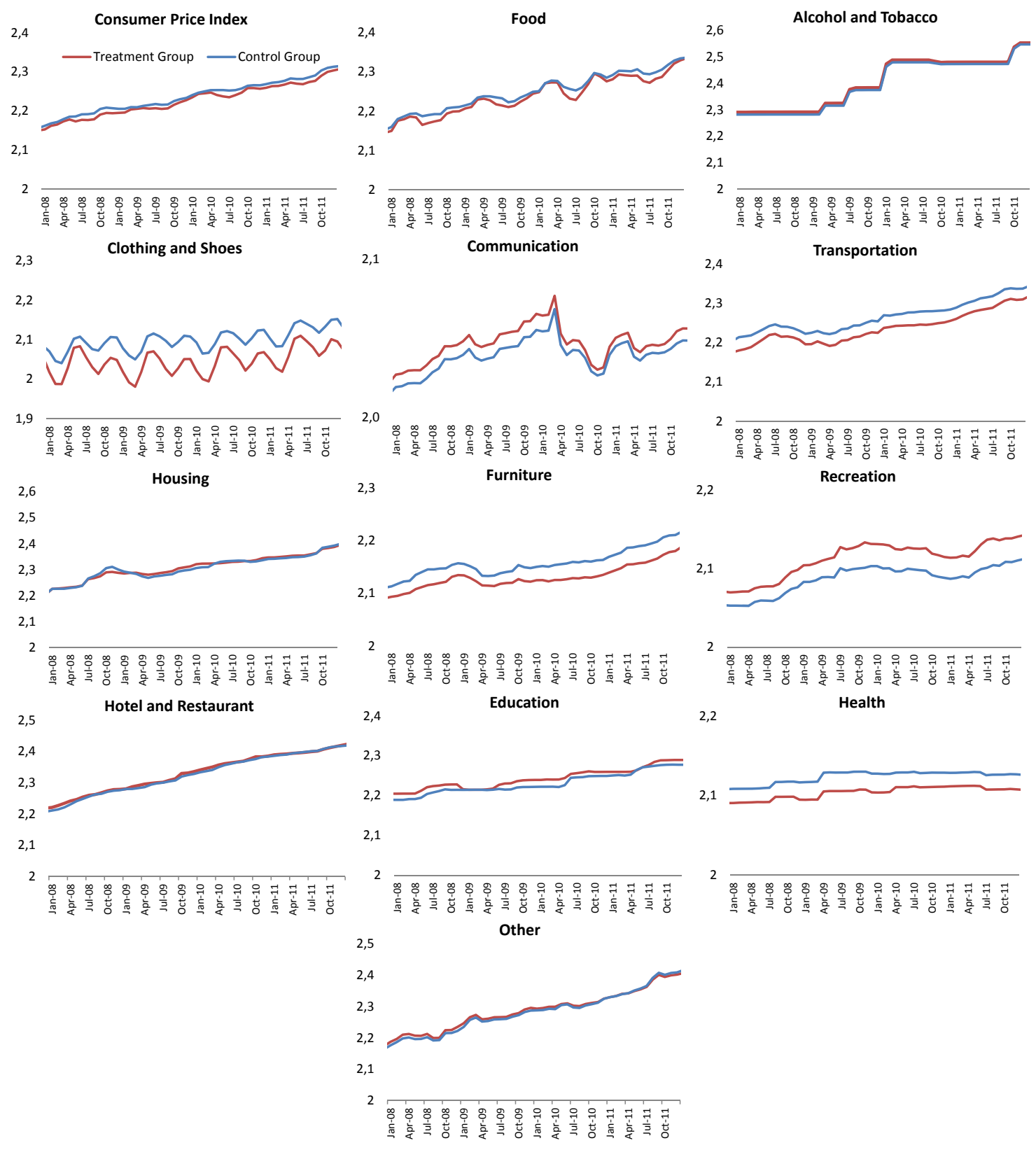

Figure 3: Prior trends by broad categories. Red color: treatment region. Blue color: control region. The $y$-axis describe the natural logarithm of the corresponding price index (2003=100 for all categories). The trends are plotted for the pre-immigration period - between Jan 2008-Dec 2011. 
12 Broad Categories in the CPI

Food and Non-alcoholic Beverages

Alcoholic Beverages and Tobacco

Clothing and Footwear

Housing, Water, Electricity, Gas, and Other Fuels

Furnishings, Household Equipment, Routine Maintenance of the House

Health

Transport

Communications

Recreation and Culture

Education

Hotels, Cafes, and Restaurants

Miscellaneous Goods and Services

Table 1: 12 Product Categories: A list of 12 broad product categories in the CPI. 
44 Sub-categories in the CPI

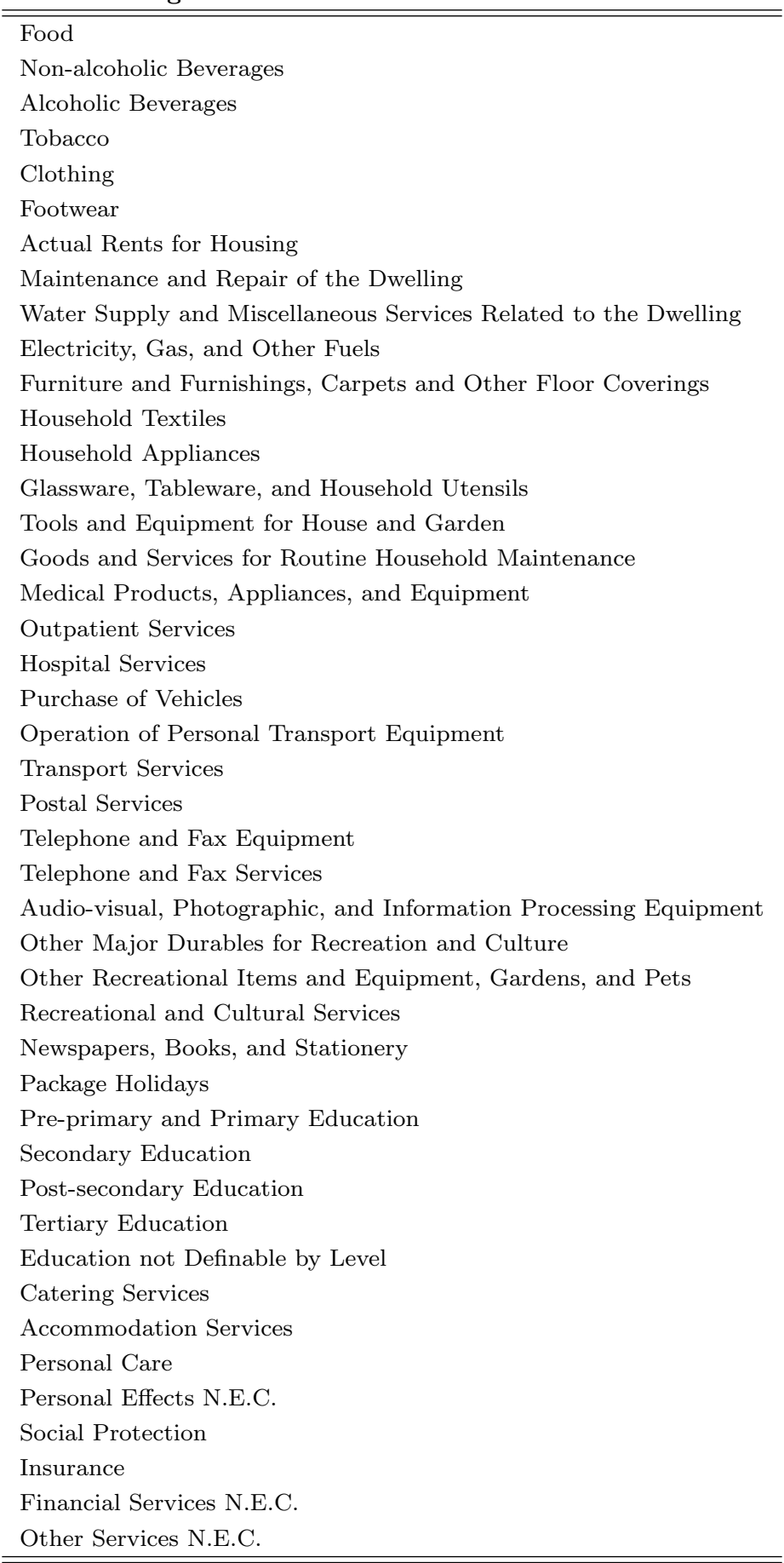

Table 2: 44 Product Sub-categories: A list of 44 product sub-categories in the CPI. 
Dependent Variable: Natural Logarithm of Price Levels

\begin{tabular}{|c|c|c|c|}
\hline \multicolumn{4}{|l|}{ ALL ITEMS } \\
\hline Variable & {$[1]$} & {$[2]$} & {$[3]$} \\
\hline Refugee effect $(I=1 \& D=1)$ & $\begin{array}{c}-0.0369^{* * *} \\
(0.0030)\end{array}$ & $\begin{array}{c}-0.0327^{* * *} \\
(0.0029)\end{array}$ & $\begin{array}{c}-0.0249^{* * *} \\
(0.0028)\end{array}$ \\
\hline Product class fixed effects (broad) & Yes & No & No \\
\hline Product class fixed effects (narrow) & No & Yes & No \\
\hline Product fixed effects & No & No & Yes \\
\hline Year fixed effects & Yes & Yes & Yes \\
\hline Region fixed effects & Yes & Yes & Yes \\
\hline Month-of-year fixed effects & Yes & Yes & Yes \\
\hline Intercept & $\begin{array}{c}1.3543^{* * *} \\
(0.0134)\end{array}$ & $\begin{array}{c}1.3720^{* * *} \\
(0.0121)\end{array}$ & $\begin{array}{c}1.4210^{* * *} \\
(0.0193)\end{array}$ \\
\hline$R^{2}$ & 0.273 & 0.746 & 0.992 \\
\hline \# of Obs. & 216,932 & 216,932 & 216,932 \\
\hline
\end{tabular}

Table 3: Natural Logarithm of Price Levels (All Items): ***, **, and * refer to 1\%, 5\%, and 10\% significance levels, respectively. Standard errors clustered with respect to the month of observation are reported in parentheses. The prices are weighted by the CPI weights, which reflect the weight of the corresponding item in households' consumption basket. The product fixed effects for broad (column [1]) and narrow (column [2]) classifications control for 12 and 44 product categories, respectively. In column [3], we control for the fixed effects for 437 individual-level products. $I=1$ refers to the refugee-receiving area and $D=1$ refers to the post-immigration period. The total number of price observations for all items over the data horizon is 216,932 .

Dependent Variable: Natural Logarithm of Price Levels

\begin{tabular}{|c|c|c|c|}
\hline \multicolumn{4}{|l|}{ GOODS } \\
\hline Variable & {$[1]$} & {$[2]$} & {$[3]$} \\
\hline Refugee effect $(I=1 \& D=1)$ & $\begin{array}{c}-0.0424^{* * *} \\
(0.0033)\end{array}$ & $\begin{array}{c}-0.0356^{* * *} \\
(0.0032)\end{array}$ & $\begin{array}{c}-0.0264^{* * *} \\
(0.0032)\end{array}$ \\
\hline Product class fixed effects (broad) & Yes & No & No \\
\hline Product class fixed effects (narrow) & No & Yes & No \\
\hline Product fixed effects & No & No & Yes \\
\hline Year fixed effects & Yes & Yes & Yes \\
\hline Region fixed effects & Yes & Yes & Yes \\
\hline Month-of-year fixed effects & Yes & Yes & Yes \\
\hline Intercept & $\begin{array}{c}1.3816^{* * *} \\
(0.0059)\end{array}$ & $\begin{array}{c}1.3976^{* * *} \\
(0.0050)\end{array}$ & $\begin{array}{c}1.4486^{* * *} \\
(0.0135)\end{array}$ \\
\hline$R^{2}$ & 0.356 & 0.780 & 0.997 \\
\hline \# of Obs. & 166,926 & 166,926 & 166,926 \\
\hline
\end{tabular}

Table 4: Natural Logarithm of Price Levels (Goods): ***, **, and $*$ refer to $1 \%, 5 \%$, and $10 \%$ significance levels, respectively. Standard errors clustered with respect to the month of observation are reported in parentheses. The prices are weighted by the CPI weights, which reflect the weight of the corresponding item in households' consumption basket. The product fixed effects for broad (column [1]) and narrow (column [2]) classifications control for 10 and 26 product categories, respectively. In column [3], we control for the fixed effects for 340 individual-level goods. $I=1$ refers to the refugee-receiving area and $D=1$ refers to the post-immigration period. The total number of price observations for all items over the data horizon is 166,926. 
Dependent Variable: Natural Logarithm of Price Levels

\begin{tabular}{l|c|c|c}
\hline \multicolumn{5}{l}{ SERVICES } & {$[\mathbf{1}]$} & {$[\mathbf{2}]$} & {$[\mathbf{3}]$} \\
\hline \hline Variable & $-0.0155^{* * *}$ & $-0.0216^{* * *}$ & $-0.0216^{* * *}$ \\
& $(0.0016)$ & $(0.0032)$ & $(0.0032)$ \\
\hline Refugee effect $(I=1 \& D=1)$ & Yes & No & No \\
& No & Yes & No \\
Product class fixed effects (broad) & No & No & Yes \\
Product fixed effects & Yes & Yes & Yes \\
Year fixed effects & Yes & Yes & Yes \\
Region fixed effects & Yes & Yes & Yes \\
Month-of-year fixed effects & $3.6581^{* * *}$ & $3.4873^{* * *}$ & $3.4644^{* * *}$ \\
\hline Intercept & $(0.0605)$ & $(0.0613)$ & $(0.0608)$ \\
& 0.240 & 0.546 & 0.952 \\
\hline$R^{2}$ & 50,006 & 50,006 & 50,006 \\
$\#$ of Obs. & \multicolumn{3}{|c}{} \\
\hline \hline
\end{tabular}

Table 5: Natural Logarithm of Price Levels (Services): ***, **, and * refer to 1\%, 5\%, and $10 \%$ significance levels, respectively. Standard errors clustered with respect to the month of observation are reported in parentheses. The prices are weighted by the CPI weights, which reflect the weight of the corresponding item in households' consumption basket. The product fixed effects for broad (column [1]) and narrow (column [2]) classifications control for 8 and 25 product categories, respectively. In column [3], we control for the fixed effects for 97 individual-level services. $I=1$ refers to the refugee-receiving area and $D=1$ refers to the post-immigration period. The total number of price observations for all services items over the data horizon is 50,006 . 
Dependent Variable: Natural Logarithm of Price Levels INFORMAL LABOR INTENSIVE

\begin{tabular}{l|c|c|c}
\hline \hline Variable & {$[\mathbf{1}]$} & {$[\mathbf{2}]$} & {$[\mathbf{3}]$} \\
\hline Refugee effect $(I=1 \& D=1)$ & $-0.0386^{* * *}$ & $-0.0385^{* * *}$ & $-0.0384^{* * *}$ \\
& $(0.0045)$ & $(0.0045)$ & $(0.0045)$ \\
\hline Product class fixed effects (broad) & Yes & No & No \\
Product class fixed effects (narrow) & No & Yes & No \\
Product fixed effects & No & No & Yes \\
\hline Year fixed effects & Yes & Yes & Yes \\
Region fixed effects & Yes & Yes & Yes \\
Month-of-year fixed effects & Yes & Yes & Yes \\
\hline Intercept & $3.4084^{* * *}$ & $1.4084^{* * *}$ & $1.4654^{* * *}$ \\
& $(0.0066)$ & $(0.0066)$ & $(0.0126)$ \\
\hline$R^{2}$ & 0.434 & 0.442 & 0.991 \\
$\#$ of Obs. & 99,871 & 99,871 & 99,871 \\
\hline \hline
\end{tabular}

Table 6: Natural Logarithm of Price Levels (Informal Labor Intensive): ${ }^{* * *}$, ${ }^{* *}$, and ${ }^{*}$ refer to $1 \%, 5 \%$, and $10 \%$ significance levels, respectively. Standard errors clustered with respect to the month of observation are reported in parentheses. The prices are weighted by the CPI weights, which reflect the weight of the corresponding item in households' consumption basket. The product fixed effects for broad (column [1]) and narrow (column [2]) classifications control for 8 and 25 product categories, respectively. In column [3], we control for the fixed effects for 208 individual-level items. $I=1$ refers to the refugee-receiving area and $D=1$ refers to the post-immigration period. The total number of price observations for all services items over the data horizon is 99,871 . 
Dependent Variable: Natural Logarithm of Price Levels FORMAL LABOR INTENSIVE

\begin{tabular}{l|c|c|c}
\hline \hline Variable & {$[\mathbf{1}]$} & {$[\mathbf{2}]$} & {$[\mathbf{3}]$} \\
\hline Refugee effect $(I=1 \& D=1)$ & $-0.0351^{* * *}$ & $-0.0241^{* * *}$ & $-0.0039^{* * *}$ \\
& $(0.0014)$ & $(0.0010)$ & $(0.0007)$ \\
\hline Product class fixed effects (broad) & Yes & No & No \\
Product class fixed effects (narrow) & No & Yes & No \\
Product fixed effects & No & No & Yes \\
\hline Year fixed effects & Yes & Yes & Yes \\
Region fixed effects & Yes & Yes & Yes \\
Month-of-year fixed effects & Yes & Yes & Yes \\
\hline Intercept & $0.9860^{* * *}$ & $0.9983^{* * *}$ & $3.0808^{* * *}$ \\
& $(0.0366)$ & $(0.0333)$ & $(0.0268)$ \\
\hline$R^{2}$ & 0.192 & 0.798 & 0.991 \\
$\#$ of Obs. & 117,061 & 117,061 & 117,061 \\
\hline \hline
\end{tabular}

Table 7: Natural Logarithm of Price Levels (Formal Labor Intensive): ***, ${ }^{* *}$, and $*$ refer to 1\%, 5\%, and $10 \%$ significance levels, respectively. Standard errors clustered with respect to the month of observation are reported in parentheses. The prices are weighted by the CPI weights, which reflect the weight of the corresponding item in households' consumption basket. The product fixed effects for broad (column [1]) and narrow (column [2]) classifications control for 8 and 25 product categories, respectively. In column [3], we control for the fixed effects for 229 individual-level items. $I=1$ refers to the refugee-receiving area and $D=1$ refers to the post-immigration period. The total number of price observations for all services items over the data horizon is 117,061 . 
Dependent Variable: Natural Logarithm of Price Levels

\begin{tabular}{l|c}
\hline BY BROAD PRODUCT CLASS - SEPARATE REGRESSIONS \\
\hline \hline Product Class & Refugee effect $(I=1$ \& $D=1)$ \\
\hline Food & $-0.0446^{* * *}$ \\
& $(0.0055)$ \\
\hline Alcohol and Tobacco & $-0.0159^{* *}$ \\
& $(0.0074)$ \\
\hline Clothing and Shoes & 0.0007 \\
& $(0.0059)$ \\
\hline Housing & $-0.0046^{* *}$ \\
& $(0.0019)$ \\
\hline Furniture & 0.0017 \\
& $(0.0018)$ \\
\hline Health & $0.0188^{* * *}$ \\
& $(0.0042)$ \\
\hline Transportation & $0.0075^{* * *}$ \\
& $(0.0007)$ \\
\hline Communication & 0.0004 \\
& $(0.0004)$ \\
\hline Recreation & -0.0029 \\
\hline Education & $(0.0018)$ \\
\hline Hotel and Restaurant & $-0.1053^{* * *}$ \\
& $(0.0061)$ \\
\hline \hline
\end{tabular}

Table 8: Natural Logarithm of Price Levels (By 12 Product Classes): ***, **, and * refer to 1\%, 5\%, and $10 \%$ significance levels, respectively. Standard errors clustered with respect to the month of observation are reported in parentheses. The prices are weighted by the CPI weights, which reflect the weight of the corresponding item in households' consumption basket. 437 product fixed effects are controlled for. $I=1$ refers to the refugee-receiving area and $D=1$ refers to the post-immigration period. 
Dependent Variable: Natural Logarithm of Price Levels

\begin{tabular}{|c|c|c|c|c|c|c|}
\hline \multicolumn{7}{|c|}{ BASIC vs LUXURY FOOD ITEMS } \\
\hline \multirow[t]{2}{*}{ Variable } & \multicolumn{2}{|c|}{$[1]$} & \multicolumn{2}{|c|}{$[2]$} & \multicolumn{2}{|c|}{$[3]$} \\
\hline & Basic & Luxury & Basic & Luxury & Basic & Luxury \\
\hline Refugee effect & $\begin{array}{c}-0.0812^{* * *} \\
(0.0101)\end{array}$ & $\begin{array}{c}-0.0119 * * * \\
(0.0033)\end{array}$ & $\begin{array}{c}-0.0726^{* * *} \\
(0.0065)\end{array}$ & $\begin{array}{c}-0.0194^{* * *} \\
(0.0045)\end{array}$ & $\begin{array}{c}-0.0705^{* * *} \\
(0.0059)\end{array}$ & $\begin{array}{c}-0.0212^{* * *} \\
(0.0055)\end{array}$ \\
\hline Product fixed effects & Yes & Yes & Yes & Yes & Yes & Yes \\
\hline Year fixed effects & Yes & Yes & Yes & Yes & Yes & Yes \\
\hline Region fixed effects & Yes & Yes & Yes & Yes & Yes & Yes \\
\hline Month-of-year fixed effects & Yes & Yes & Yes & Yes & Yes & Yes \\
\hline Intercept & $\begin{array}{c}1.4551^{* * *} \\
(0.0168)\end{array}$ & $\begin{array}{c}4.0360^{* * *} \\
(0.0237)\end{array}$ & $\begin{array}{c}1.3815^{* * *} \\
(0.0194)\end{array}$ & $\begin{array}{c}3.9784^{* * *} \\
(0.0223)\end{array}$ & $\begin{array}{c}1.3696^{* * *} \\
(0.0201)\end{array}$ & $\begin{array}{c}3.9639 * * * \\
(0.0224)\end{array}$ \\
\hline$R^{2}$ & 0.945 & 0.973 & 0.947 & 0.974 & 0.949 & 0.975 \\
\hline \# of Obs. & 8,280 & 7,092 & 23,920 & 20,488 & 20,240 & 17,336 \\
\hline
\end{tabular}

Table 9: Basic versus Luxury Food Items: ***, ${ }^{* *}$, and $*$ refer to $1 \%, 5 \%$, and $10 \%$ significance levels, respectively. Standard errors clustered with respect to the month of observation are reported in parentheses. The prices are weighted by the CPI weights, which reflect the weight of the corresponding item in households' consumption basket. [1] constructs the DID across the treatment area versus the East Anatolia as the control group. [2] constructs the DID across the treatment area versus the rest of the country as the control group. [3] constructs the DID across the treatment area versus the rest of the country excluding east Anatolia as the control group. According to the typical consumption basket in Turkey, basic food items are rice, wheat, wheat flour, bread, cracker, wafer, macaroni, poultry, yoghurt, white cheese, margarine, sun-flower oil, water melon, tomato, onion, and potato. Luxury food items are baby food, patisserie items, wermicelli, cereal, veal, tulum cheese, butter, olive oil, cherry, pomegranate, hazelnut, pistachio, okra, green pea, chocolate, and packaged soup. The constant term in the regressions demonstrate the large price differencials between the basic versus luxury food items.

\begin{tabular}{|c|c|c|c|}
\hline \multicolumn{4}{|c|}{ INTERNAL MIGRATION OF NATIVES } \\
\hline & In-migration & Out-migration & Net-migration \\
\hline Refugee effect & $\begin{array}{l}-0.3399 \\
(0.2404)\end{array}$ & $\begin{array}{l}-0.0611 \\
(0.2711)\end{array}$ & $\begin{array}{l}-0.2788 \\
(0.4870)\end{array}$ \\
\hline $\begin{array}{l}\text { Year fixed effects } \\
\text { City fixed effects }\end{array}$ & $\begin{array}{l}\text { Yes } \\
\text { Yes }\end{array}$ & $\begin{array}{l}\text { Yes } \\
\text { Yes }\end{array}$ & $\begin{array}{l}\text { Yes } \\
\text { Yes }\end{array}$ \\
\hline Intercept & $\begin{array}{c}2.4068^{* * *} \\
(0.0465)\end{array}$ & $\begin{array}{c}2.6704^{* * *} \\
(0.1386)\end{array}$ & $\begin{array}{c}-0.2636^{*} \\
(0.1456)\end{array}$ \\
\hline $\begin{array}{l}R^{2} \\
\# \text { of Obs. }\end{array}$ & $\begin{array}{c}0.839 \\
130\end{array}$ & $\begin{array}{c}0.869 \\
130\end{array}$ & $\begin{array}{c}0.612 \\
130\end{array}$ \\
\hline
\end{tabular}

Table 10: Internal migration of natives: ***,**, and * refer to $1 \%, 5 \%$, and $10 \%$ significance levels, respectively. Standard errors are clustered at the city level. TURKSTAT annual internal migration dataset is used at the city level for the period 2010-2014. We set east Anatolia as our control region in all three regressions. Observations are weighted by city populations. 
Dependent Variable: Natural Logarithm of Trade Volume

\section{EXPORTS and IMPORTS}

\begin{tabular}{l|c|c|c|c|c|c}
\hline \hline Variable & \multicolumn{2}{|c|}{$[\mathbf{1}]$} & \multicolumn{2}{c|}{$[\mathbf{2}]$} & \multicolumn{2}{c}{$[\mathbf{3}]$} \\
\hline & Exports & Imports & Exports & Imports & Exports & Imports \\
\hline Refugee effect & -0.0088 & -0.3392 & -0.0132 & -0.0830 & -0.0144 & -0.0208 \\
& $(0.1888)$ & $(0.2040)$ & $(0.1097)$ & $(0.1594)$ & $(0.1088)$ & $(0.1592)$ \\
\hline Product fixed effects & Yes & Yes & Yes & Yes & Yes & Yes \\
\hline Year fixed effects & Yes & Yes & Yes & Yes & Yes & Yes \\
City fixed effects & Yes & Yes & Yes & Yes & Yes & Yes \\
Month-of-year fixed effects & Yes & Yes & Yes & Yes & Yes & Yes \\
\hline Intercept & $18.575^{* * *}$ & $18.814^{* * *}$ & $18.508^{* * *}$ & $18.867^{* * *}$ & $18.463^{* * *}$ & $18.890^{* * *}$ \\
& $(0.0996)$ & $(0.1276)$ & $(0.0705)$ & $(0.1028)$ & $(0.0705)$ & $(0.1047)$ \\
\hline$R^{2}$ & 0.922 & 0.875 & 0.948 & 0.920 & 0.954 & 0.940 \\
$\#$ of Obs. & 1,662 & 1,590 & 4,745 & 4,678 & 3,923 & 3,928 \\
\hline \hline
\end{tabular}

Table 11: Exports and Imports: ${ }^{* * *},{ }^{* *}$, and $*$ refer to $1 \%, 5 \%$, and $10 \%$ significance levels, respectively. Standard errors clustered with respect to the month of observation are reported in parentheses. Monthly TURKSTAT trade volume data is used at the city level for the period 2010-2014. [1] constructs the DID across the treatment area versus the East Anatolia as the control group. [2] constructs the DID across the treatment area versus the rest of the country as the control group. [3] constructs the DID across the treatment area versus the rest of the country excluding east Anatolia as the control group.

Dependent Variable: Natural Logarithm of Price Levels

\begin{tabular}{|c|c|c|c|}
\hline \multicolumn{4}{|l|}{ ALL ITEMS } \\
\hline Variable & Total & Formal & Informal \\
\hline \multicolumn{4}{|c|}{ A. Post-Immigration Period: 2012} \\
\hline Refugee effect $(I=1 \& D=1)$ & $\begin{array}{c}-0.0149^{* * *} \\
(0.0031)\end{array}$ & $\begin{array}{c}-0.0066^{* *} \\
(0.0024)\end{array}$ & $\begin{array}{c}-0.0195^{* * *} \\
(0.0040)\end{array}$ \\
\hline \multicolumn{4}{|c|}{ B. Post-Immigration Period: 2013} \\
\hline Refugee effect $(I=1 \& D=1)$ & $\begin{array}{c}-0.0273^{* * *} \\
(0.0027)\end{array}$ & $\begin{array}{c}-0.0052^{* *} \\
(0.0024)\end{array}$ & $\begin{array}{c}-0.0420^{* * *} \\
(0.0031)\end{array}$ \\
\hline \multicolumn{4}{|c|}{ C. Post-Immigration Period: 2014} \\
\hline Refugee effect $(I=1 \& D=1)$ & $\begin{array}{c}-0.0317^{* * *} \\
(0.0026) \\
\end{array}$ & $\begin{array}{l}-0.0038 \\
(0.0027) \\
\end{array}$ & $\begin{array}{c}-0.0505^{* * *} \\
(0.0031) \\
\end{array}$ \\
\hline Product fixed effects & Yes & Yes & Yes \\
\hline Year fixed effects & Yes & Yes & Yes \\
\hline Region fixed effects & Yes & Yes & Yes \\
\hline Month-of-year fixed effects & Yes & Yes & Yes \\
\hline
\end{tabular}

Table 12: Robustness Exercise - Time Variation in Refugee Intensity: ***, ${ }^{* *}$, and ${ }^{*}$ refer to 1\%, $5 \%$, and $10 \%$ significance levels, respectively. Standard errors clustered with respect to the month of observation are reported in parentheses. The prices are weighted by the CPI weights, which reflect the weight of the corresponding item in households' consumption basket. $I=1$ refers to the refugee-receiving area and $D=1$ refers to the post-immigration period. Panels $A, B$, and $C$ separately set 2012, 2013, and 2014 as the postimmigration period, respectively. 
Dependent Variable: Natural Logarithm of Price Levels

\begin{tabular}{l|c|c|c}
\hline \hline Variable & Total & Formal & Informal \\
\hline Refugee effect $(I=1 \& D=1)$ & $-0.0170^{* * *}$ & 0.0034 & $-0.0274^{* * *}$ \\
& $(0.0030)$ & $(0.0009)$ & $(0.0024)$ \\
\hline Product fixed effects & Yes & Yes & Yes \\
Year fixed effects & Yes & Yes & Yes \\
Region fixed effects & Yes & Yes & Yes \\
Month-of-year fixed effects & Yes & Yes & Yes \\
\hline Intercept & $1.3897^{* * *}$ & $3.0177^{* * *}$ & $1.4231^{* * *}$ \\
& $(0.0165)$ & $(0.0183)$ & $(0.0138)$ \\
\hline$R^{2}$ & 0.991 & 0.990 & 0.993 \\
$\#$ of Obs. & 628,476 & 264,120 & 364,356 \\
\hline \hline
\end{tabular}

Table 13: Robustness Exercise - Alternative control region (All Turkey except the treatment region): ${ }^{* *},{ }^{* *}$, and $*$ refer to $1 \%, 5 \%$, and $10 \%$ significance levels, respectively. Standard errors clustered with respect to the month of observation are reported in parentheses. The prices are weighted by the CPI weights, which reflect the weight of the corresponding item in households' consumption basket. The product fixed effects for 437 individual-level products are controlled for. $I=1$ refers to the refugee-receiving area and $D=1$ refers to the post-immigration period.

Dependent Variable: Natural Logarithm of Price Levels

\begin{tabular}{l|c|c|c}
\hline \hline Variable & Total & Formal & Informal \\
\hline Refugee effect $(I=1 \& D=1)$ & $-0.0152^{* * *}$ & $0.0061^{* * *}$ & $-0.0261^{* * *}$ \\
& $(0.0016)$ & $(0.0011)$ & $(0.0023)$ \\
\hline Product fixed effects & Yes & Yes & Yes \\
Year fixed effects & Yes & Yes & Yes \\
Region fixed effects & Yes & Yes & Yes \\
Month-of-year fixed effects & Yes & Yes & Yes \\
\hline Intercept & $1.3750^{* * *}$ & $3.0041^{* * *}$ & $1.4082^{* * *}$ \\
& $(0.0167)$ & $(0.0185)$ & $(0.0139)$ \\
\hline$R^{2}$ & 0.992 & 0.990 & 0.993 \\
$\#$ of Obs. & 532,204 & 223,560 & 308,644 \\
\hline \hline
\end{tabular}

Table 14: Robustness Exercise - Alternative control region (All Turkey except the treatment and original control regions): ${ }^{* * *},{ }^{* *}$, and $*$ refer to $1 \%, 5 \%$, and $10 \%$ significance levels, respectively. Standard errors clustered with respect to the month of observation are reported in parentheses. The prices are weighted by the CPI weights, which reflect the weight of the corresponding item in households' consumption basket. The product fixed effects for 437 individual-level products are controlled for. $I=1$ refers to the refugee-receiving area and $D=1$ refers to the post-immigration period. 
Dependent Variable: Natural Logarithm of Trade Volume REFUGEE INTENSITY - REGIONAL VARIATION

\begin{tabular}{l|c|c|c|c|c}
\hline \hline & {$[1]$} & {$[2]$} & {$[3]$} & {$[4]$} & {$[5]$} \\
\hline Refugee effect & $-0.0185^{* * *}$ & $-0.0462^{* * *}$ & $-0.0135^{* * *}$ & $-0.0168^{* * *}$ \\
$(0.0039)$ & $(0.0062)$ & $(0.0028)$ & $(0.0038)$ & $\begin{array}{c}-0.0292^{* * *} \\
(0.0036)\end{array}$ \\
\hline Ref./Pop. Ratio & 0.0249 & 0.1682 & 0.0638 & 0.0422 & 0.0487 \\
\hline Product fixed effects & Yes & Yes & Yes & Yes & Yes \\
Year fixed effects & Yes & Yes & Yes & Yes & Yes \\
Region fixed effects & Yes & Yes & Yes & Yes & Yes \\
Month-of-year fixed effects & Yes & Yes & Yes & Yes & Yes \\
\hline Intercept & $1.4066^{* * *}$ & $1.3852^{* * *}$ & $1.3463^{* * *}$ & $1.4113^{* * *}$ & $1.4096^{* * *}$ \\
& $(0.0200)$ & $(0.0186)$ & $(0.0181)$ & $(0.0180)$ & $(0.0169)$ \\
\hline$R^{2}$ & 0.992 & 0.992 & 0.992 & 0.992 & 0.992 \\
$\#$ of Obs. & 120,553 & 120,434 & 120,385 & 120,206 & 120,469 \\
\hline \hline
\end{tabular}

Table 15: Robustness Exercise - Regional Variation in Refugee Intensity: ${ }^{* * *},{ }^{* *}$, and ${ }^{*}$ refer to $1 \%, 5 \%$, and $10 \%$ significance levels, respectively. Standard errors clustered with respect to the month of observation are reported in parentheses. The sub-regions are determined based on the NUTS2-level regional classification. [1] sets Adana and Mersin as the treatment group. [2] sets Gaziantep, Adiyaman, and Kilis as the treatment group. [3] sets Hatay, Kahramanmaras, and Osmaniye as the treatment group. [4] sets Mardin, Batman, Sirnak, and Siirt as the treatment group. [5] sets Sanliurfa and Diyarbakir as the treatment group. Control group is the same as our baseline specification (eastern Anatolia). See Figure (2) for a map of refugee intensities across these cities.

\begin{tabular}{l|c|c|c}
\multicolumn{4}{l}{ Dependent Variable: Natural Logarithm of Price Levels } \\
\hline 2011 AS THE PLACEBO TREATMENT YEAR & \\
\hline \hline & {$[1]$} & {$[2]$} & {$[3]$} \\
\hline Refugee effect $(I=1 \& D=1)$ & -0.0005 & -0.0019 & -0.0052 \\
& $(0.0040)$ & $(0.0037)$ & $(0.0032)$ \\
\hline Product class fixed effects (broad) & Yes & No & No \\
Product class fixed effects (narrow) & No & Yes & No \\
Product fixed effects & No & No & Yes \\
\hline Year fixed effects & Yes & Yes & Yes \\
Region fixed effects & Yes & Yes & Yes \\
Month-of-year fixed effects & Yes & Yes & Yes \\
\hline Intercept & $1.3567^{* * *}$ & $1.3740^{* * *}$ & $1.3428^{* * *}$ \\
& $(0.0154)$ & $(0.0129)$ & $(0.0279)$ \\
\hline$R^{2}$ & 0.272 & 0.742 & 0.993 \\
$\#$ of Obs. & 212,664 & 212,664 & 212,664 \\
\hline \hline
\end{tabular}

Table 16: Robustness Exercise - 2011 as the Placebo Treatment Year: ***, ${ }^{* *}$, and $*$ refer to 1\%, 5\%, and $10 \%$ significance levels, respectively. Standard errors clustered with respect to the month of observation are reported in parentheses. The prices are weighted by the CPI weights, which reflect the weight of the corresponding item in households' consumption basket. $I=1$ refers to the refugee-receiving area and $D=1$ refers to the post-immigration period. 
APPENDIX: Formal versus Informal Labor Intensive Items

\begin{tabular}{|c|c|c|c|}
\hline Accomodations Services (Univ.) & Children's Sport Shoes & Firewood Price & Men's Hairdressing \\
\hline Actual Rent & Children's Sweatshirt & First-Aid Tools & Men's Jacket \\
\hline Air Conditioner & Children's Toys & Flash Heaters & Men's Pajamas \\
\hline Airplane Fare & Children's Tracksuit & Flat Bread & Men's Pullover \\
\hline Almond & Children's Trousers & Fresh Fish & Men's Shirt \\
\hline Aluminium and Strech Foil & Children's T-Shirt & Fruit Juice & Men's Socks \\
\hline Apple & Children's Underwear & Furnace with Gas & Men's Sport Shoes \\
\hline Apricot & Chips and Appetizers & Furnace with Oven & Men's Suit \\
\hline Articles for Cleaning & Chocolate & Garlic & Men's Sweatshirt \\
\hline Articles for Dental Hygiene & Chocolate Cream & Garlic-Flavored Sausage & Men's Tracksuit \\
\hline Aspirator & Cigarettes & Glass Household Utentsils & Men's Trousers \\
\hline Automobile $(2000 \mathrm{cc})$ & Cinema & Granulated Sugar & Men's T-Shirt \\
\hline Automobile (Diesel) & City Bus Fare (Inter-Urban) & Grape & Men's Underwear \\
\hline Automobile (Gasoline) & Clinical Thermometer & Grape Molasses & Milk \\
\hline Ayran & Coal Price & Green Bean & Mineral Water \\
\hline Ayran Served & Cocoa & Green Onion & Mini Bus Fare \\
\hline Baby Carriage and Car Seat & Cocoa Beverages & Green Pea & Mixture Fabrics \\
\hline Baby Food & Coke & Green Pepper & Motor Oil \\
\hline Baby Napkin & Cold Drinks Served & Hair Care Appliances & MR Fee \\
\hline Baby's Pajamas & Cold Meals & Hair Care Products & Mushroom \\
\hline Baby's Socks & Cologne & Halvah & Music CD \\
\hline Baby's Underwear & Combi Boiler & Hamburgers and Sandwiches & Music Equipment \\
\hline Baking Powder & Condiment-Spices & Hazelnut (without Shells) & Mutton \\
\hline Banana & Contact Lense & Herbal Tea & National Lottery \\
\hline Banking Service & Corn Oil & Hire of Car Fee & Natural Childbirth Fee \\
\hline Bath Soap & Corrective Eye-Glasses & Holiday Candy & Natural Gas \\
\hline Bath Stove & Cotton Fabric & Honey & Natural Gas Subscription Fee \\
\hline Battery & Cotton Wool & Horse Racing & Nesting Table \\
\hline Bed Base & Courses Language Education & Hospital Bed Fee & Newspapers \\
\hline Bed Clothes & Cracker & Hot Drinks Served & Notebook \\
\hline Bed Cover & Cream Cheese & Hotel Charge & Offal \\
\hline Bedroom Furniture & Cream-Cake and Patisserie & Household Textile Fabrics & Okra \\
\hline Beer & Créche and Day-Care Center & Hygienic Pad for Women & Olive \\
\hline Belt & Cube Sugar & Ice-Cream & Olive Oil \\
\hline Bicycle & Cucumber & Insurance for Burglary \& Disasters & Onion \\
\hline Biscuit & Curtain & Insurance for Health & Orange \\
\hline Blanket & Dentist Fee (Filling) & Insurance for Transport & Other Books \\
\hline Blender & Dentist Fee (Pulling) & Iron & Other Electrical Equipments \\
\hline Boat Fare & Deodorants & Items for Sport and Recreation & Other Non-Electrical Appliances \\
\hline Body Cream and Lotion & Dessert & Jam & Other Pulse \\
\hline Boiled and Pounded Wheat & Desserts in Restaurants & Jewellery (Gold) & Other Recreational Services \\
\hline Box of Color Pencils for Painting & Detergents (for Laundry) & Kasar Cheese & Other Stationery \\
\hline Bread & Diesel & Kindergarten Fees & Other Steel Kitchen Utentils \\
\hline Bridge Fare & Dining Room Furniture & Kitchen Paper and Napkins & Oven \\
\hline Broiled Meat (Kebap) & Dish Antenna and Receiver & Kiwi & Overalls for Baby \\
\hline Bus Fare (Intra-Urban) & Dish Washing Machine & Knitting Wool & Package Holidays (Abroad) \\
\hline Butter & Dishwasher Detergents & Laboratory Analysis Fee & Package Holidays (Above 1 Week) \\
\hline Cabbage & Disinfectants and Insecticidies & Lacework String & Package Holidays (Weekend) \\
\hline Cable TV Service Fee & Doner in Bread & Leek & Packaged Soup \\
\hline Cake & Door Fittings & Lemon & Paper Tissue \\
\hline Camera & Double Bed & Lentils & Parsley \\
\hline Canned Vegetables & Dried Apricot & Lettuce & Patisserie Products Served \\
\hline Car Park Fee & Driver Course Fare & Liquid Petroleum Gas (LPG) & Payment for Delivery of Letters \\
\hline Carbonated Fruity Beverages & Dry Bean & Living Room Furniture & Payment for Delivery of Parcell \\
\hline Cargo Fee & Dry Cleaning & Lottery (Chance Ball) & Payment for Photocopies \\
\hline Carpet & DVD Player & Lottery (Number 10) & PC and Laptop \\
\hline Carpet \& Other Coverings Cleaning & Egg & Lottery Game (Iddaa) & PC Equipments \\
\hline Carrot & Eggplant & Lotto & Peach \\
\hline Catchup & Electric Bulb & Macaroni & Peanuts \\
\hline Cauliflower & Electric Razors & Magazines & Pear \\
\hline CD Player & Electricity Fee & Maid and Cleaners' Fee & Pencil \\
\hline Cereal & Expenditure on Floor Covering & Maintenance \& Service for Vehicle & Perfume \\
\hline Cesarean Section Fee & Expenditure on Purchase of Glass & Maintenance for Aud.-Visual Eqp. & Petrol \\
\hline Chair & Expenditure on Wall Covering (Die) & Maintenance \& Repairs for Vehicle & Phone Cards \\
\hline Cherry & Fee for Cellular Phone Calls & Make-Up Products & Phone Machine \\
\hline Chewing Gum & Fee for Internet Connection & Manicures and Beauty Service & Phone Rates \\
\hline Chickpea & Fee for Phone Calls & Margarine & Phone Rates \\
\hline Children Books & Fee Paid for Having Pictures Taken & Mayonnaise & Phone Rates \\
\hline Children's Boots & Fee Paid for Watching Football & Medicines & Phone Rates \\
\hline Children's Coat & Fees for Secondary Education & Melon & Pillow \\
\hline Children's Footwear & Fees for University Education & Men's Anorak Coat & Pistachio \\
\hline Children's Pajamas & Fees for Legal Service & Men's Boots & Plastic Household Utentils \\
\hline Children's Pullover & Fees for Transportation Vehicle & Men's Coat & Plum \\
\hline Children's Shirt & Fees Paid to Specialist Doctor & Men's Footwear & Plumbing Items \\
\hline Children's Socks & Film Development & Men's Footwear Repair & Pomegranate \\
\hline
\end{tabular}




\begin{tabular}{|c|c|c|c|}
\hline Porcelain Household Utensils & Spare Parts and Accessories & Travel Goods & Women's Tracksuit \\
\hline Potato & Spare Parts for Mobile Phone & Tube Gas & Women's Trousers \\
\hline Poultry & Spinach & Tulle & Women's T-Shirt \\
\hline Printer & Sponge for Dish Washing & Tulum Cheese & Women's Underwear \\
\hline Private School Fees (Primary) & Stationery Papers & Turkish Coffee & X-Ray Fee \\
\hline Private School Fees (Secondary) & Steel Kitchen Utentils & Turkish Delight & Yoghurt \\
\hline Private University Fee & Stove & Ultrasound Fee & Zucchini \\
\hline Products for Maint. of Trans. Equip. & Stove Equipments & Umbrella & \\
\hline Pudding & Strawberry & Underground Fare & \\
\hline Pumpkin Seed & Stuff Pepper & University Fee & \\
\hline Purslane & Subscription Costs of Telephone & Unrecorded Dvd & \\
\hline Quilt & Suit Repair & Vacuum Cleaner & \\
\hline Quince & Suit Sewing & Vacuum Cleaner Bag & \\
\hline Radish & Sun Flower Seed & Veal & \\
\hline Raisin & Sun-Flower Oil & Veterinary Fee & \\
\hline Raki & Super Lotto & Vinegar & \\
\hline Raki and Beer Served & Surgical Operation Fee & Wafer & \\
\hline Ready-Made Coffee & Sweet Green Pepper & Walnut (without Shells) & \\
\hline Red Cabbage & Table & Washing Machine & \\
\hline Refrigerator & Tablet of Chocolate & Water & \\
\hline Refrigerator No-Frost & Tangarine & Water Fee & \\
\hline Renting of Mini Football Fields & Taxi Fare & Water Heaters & \\
\hline Repair of Household Appliances & Tea & Water Melon & \\
\hline Repair of Phone Machines & Teenager Room Furniture & Wermicelli & \\
\hline Rice & Teflon Household Utentils & Wheat Flour & \\
\hline Rice Flour & Television & Whisky & \\
\hline Roasted Chick-Pea & The Pilgrimage to Mecca & White Cheese & \\
\hline Salami & Theather & Windowpane (PVC) & \\
\hline Salt & Therapeutic Appliances & Wine & \\
\hline Sausage & Thin Dough & Women's Boots & \\
\hline Scarf & Tie & Women's Boots (with Strings) & \\
\hline School Bag & Toilet Paper & Women's Cardigan & \\
\hline School Books & Toilet Soap & Women's Coat & \\
\hline Scooter & Tolls & Women's Footwear & \\
\hline Sesame Oil & Tomato & Women's Footwear Repair & \\
\hline Sewing Thread & Tomato Sauce & Women's Hairdressing & \\
\hline Shaving Articles & Toster & Women's Jacket & \\
\hline Single Bed & Towel & Women's Pajamas & \\
\hline Skirt & Train Fare (Inter-Urban) & Women's Pullover & \\
\hline Sleep Set & Train Fare (Intra-Urban) & Women's Raincoat & \\
\hline Slipper for Woman & Tram Fare & Women's Shirt & \\
\hline Sofa & Transportation Fee & Women's Socks & \\
\hline Soups & Transportation Service & Women's Sport Shoes & \\
\hline
\end{tabular}

Note: Informal labor intensive items are reported in BOLD letters. Items produced in sectors with more than $\mathbf{5 0}$ percent of all workers are employed informally are marked as "informal labor intensive." 